\title{
1 Cycling of suspended particulate phosphorus in the redoxcline of the Cariaco Basin
}

2 Erin McParland ${ }^{\mathrm{a}, \mathrm{b}}$, Claudia R. Benitez-Nelson ${ }^{\mathrm{b}}$, Gordon T. Taylor ${ }^{\mathrm{c}}$, Robert Thunell ${ }^{\mathrm{b}}$, Anna

3 Rollings $^{\mathrm{b}}$, Laura Lorenzoni ${ }^{\mathrm{d}}$

4

5 a. Marine and Environmental Biology Program, 3616 Trousdale Parkway, University of

6 Southern California, Los Angeles, California, 90089, USA

7 b. Marine Science Program \& Department of Earth and Ocean Sciences, University of South

8 Carolina, Columbia, SC, 29208, USA

9 c. School of Marine and Atmospheric Sciences, Stony Brook University, Stony Brook, NY, 1011794, USA

11 d. College of Marine Science, University of South Florida, St. Petersburg, Florida, USA

12

*Corresponding author: Marine Science Program \& Department of Earth and Ocean Sciences,

14 University of South Carolina, Columbia, SC, 29208, USA

15 Email address: cbnelson@geol.sc.edu

18 Abstract: The Cariaco Basin, located off the coast of Venezuela, is anoxic below $250 \mathrm{~m}$ and

19 has a productive redoxcline where several chemical gradients support multiple biogeochemical

20 reactions. Thus, the Cariaco Basin is an ideal study site for investigating how redox chemistry

21 influences phosphorus (P) biogeochemistry across oxic/anoxic boundaries. While sinking

22 particles in the Cariaco Basin have been investigated previously for $\mathrm{P}$ composition and flux, this

23 is the first study to describe $\mathrm{P}$ within suspended particulate particles, a key phase connecting

24 particulate and dissolved P pools. Analysis of samples collected between April 2008 and April 
25 2012, indicates that secondary peaks in total suspended particulate P (TSPP) concentrations (88

$26 \pm 60 \mathrm{nM}$ ) were present in the redoxcline and were similar in magnitude to those measured in the

27 upper $100 \mathrm{~m}(84 \pm 77 \mathrm{nM}$ TSPP). However, the composition of TSPP was significantly different

28 between the surface and the redoxcline. Suspended soluble reactive phosphorus (SSRP) was on

29 average $3 \pm 2$ times greater in the redoxcline than observed in surface waters. Furthermore,

30 composition of the TSPP pool significantly changed from less biologically available P forms

31 ( $\sim 45 \%$ organic $\mathrm{P})$ above and below the redoxcline to more biologically available $\mathrm{P}$ forms $(\sim 80 \%$

32 loosely/oxide-bound $\mathrm{P}$ ) within the redoxcline. We argue that the abrupt increases and

33 transformations in the TSPP pool within the redoxcline result from both abiotic reactions

34 associated with a manganese and iron redox shuttle and biotic reactions associated with a large

35 and diverse chemoautotrophic prokaryotic community. These results suggest that the

36 biogeochemical cycling of $\mathrm{P}$ may be altered within oxygen depleted water columns in

37 unexpected ways.

45 Keywords: Suspended phosphorus, oxygen-depleted water columns, Cariaco Basin, euxinic 46 basin, polyphosphate 


\section{Introduction}

Large-scale dissolved oxygen depletions have profound influences on marine

50 biogeochemistry, ranging from changes in food web structure to nutrient availability and the 51 recycling of organic matter at depth (Levin 2003, Lam and Kuypers, 2011). Marine

52 environments contain several major systems where extreme changes in oxygen with depth

53 significantly impact biogeochemical cycling of major and minor elements: oxygen minimum

54 zones, euxinic basins and seas, eutrophic estuaries and fjords (Spencer and Brewer 1971,

55 Emerson et al. 1983, Stramma et al., 2010, Lam and Kuypers 2011, Kalvelage et al., 2013).

56 Oxygen minimum zones (OMZs) occur along major ocean basin boundaries, typically at

57 water depths that range from $100-1000 \mathrm{~m}$, and emanate from regions characterized by highly

58 productive surface waters (Wyrtki 1962). Limited mixing, coupled with oxygen consumption

59 during remineralization of sinking organic matter, reduces oxygen concentrations far below

60 equilibrated surface water concentrations (Codispoti et al., 2005, Karstensen et al., 2008,

61 Paulmier \& Ruiz-Pino 2009). Over the past several decades, open ocean systems have

62 experienced a significant decline in dissolved oxygen concentrations, resulting in the expansion

63 of OMZs worldwide (Stramma et al., 2008; Deutsch et al., 2011, 2014). Such expansions are

64 expected to continue in response to climate induced changes in ocean temperature and

65 circulation, which result in decreased oxygen solubility, a decline in vertical mixing, and reduced

66 subduction and advection of deep waters (Matear and Hirst 2003, Stramma et al., 2008). In

67 coastal marine systems, increased fertilizer runoff from rivers and atmospheric nitrogen

68 deposition from fossil fuel burning have also contributed to the global expansion of OMZs via

69 intensified eutrophication, which results in large-scale increases in organic matter export that

70 significantly stimulates microbial respiration in the subsurface (Jahnke 1992, Paerl 1997, Correll 
71 1998, Bennett et al., 2001, Doney 2010). Indeed, coastal OMZs have spread exponentially since

72 the 1960's (Diaz and Rosenberg 2008).

73 Euxinic basins, while less prevalent than OMZs, provide invaluable test beds for 74 examination of redox chemistry and include three major sites: the Cariaco Basin, the Black Sea 75 and the Baltic Deeps. Euxinic basins are characterized by minimal mixing with the upper ocean 76 and shallow sills that restrict vertical circulation below the surface waters, creating anoxic, 77 sulfidic bottom waters (Diaz et al. 2012). Transition zones between oxic and anoxic waters are 78 usually characterized by large hydrographic and chemical gradients due to large scale changes in 79 density structure, intense elemental cycling, and elevated microbial activity (e.g., Taylor et al., 80 2001; Murray and Yakushev 2006; Wakeham et al. 2012, Li et al. 2012). Stratified waters create 81 multiple layers of biological activity fueled by a variety of redox reactions that rely on specific 82 elements, such as sulfur, nitrogen, iron and manganese (Karl 1978, Madrid et al. 2001, Taylor et 83 al. 2006). These redox reactions are similar to those found in marine sediments, except that they 84 tend to occur over scales of tens of meters, rather than centimeters, enabling redox processes to 85 be studied in more detail. Finally, these basins are relatively small, and their enclosed nature is 86 such that climate forcing tends to be more evident in basin-wide physical, chemical and 87 biological processes (Murray et al. 2006).

88 The majority of research in these oxygen-depleted environments has understandably 89 focused on the biogeochemical cycling of elements with clear redox chemistry, such as nitrogen, 90 carbon, sulfur and trace elements (Spencer and Brewer 1971, Emerson et al. 1983, Stramma et 91 al., 2010, Lam and Kuypers 2011, Kalvelage et al., 2013). Less attention has been given to the 92 macronutrient phosphorus $(\mathrm{P})$. P is a vital nutrient utilized by all marine organisms in essential 93 biomolecules, including nucleic acids, phospholipids, ATP and other energy-conserving 
94 compounds (Benitez-Nelson et al., 2007, Diaz et al., 2012). While P is often thought to limit

95 global primary production over geologic timescales, recent evidence suggests that $\mathrm{P}$ availability

96 may also influence phytoplankton cellular composition, community structure, growth and

97 production in the modern ocean (Benitez-Nelson 2000, Paytan and McLaughlin 2007, Karl 2014,

98 Silkin et al., 2014). This has led to more focused investigations regarding P speciation and

99 cycling over short time scales (e.g., Diaz et al., 2012, Martin et al., 2014). As natural and

100 anthropogenically-induced climatic changes occur, biological production has been hypothesized

101 to become increasingly P limited (Fanning 1989, Wu et al., 2000, Karl et al., 2001, Benitez-

102 Nelson et al., 2004, Karl 2014).

103 Until recently, $\mathrm{P}$ was not considered to have extensive reduced forms in natural

104 environments, with the exception of phosphine gas $\left(\mathrm{PH}_{3}\right)$ potentially produced via microbial

105 activity under strongly reducing conditions (Pasek et al., 2013). Newer studies, however, have

106 now shown that $\mathrm{P}$ exists in a variety of reduced $\mathrm{P}$ phases (phosphonates, phosphite, and

107 hypophosphite) that are cycled rapidly in both marine and freshwater regimes (Pasek et al., 2014,

108 Van Mooy et al., 2015). Thus P biogeochemistry may be significantly influenced by redox

109 chemistry in unanticipated ways.

$110 \quad$ Many studies focusing on marine sediments and sinking particles argue for enhanced

111 regeneration of dissolved $\mathrm{P}$ forms from particulate matter under anoxic conditions, mainly as a

112 result of inorganic P release via metal oxide reduction (Dellwig et al. 2010); although the

113 magnitude of $\mathrm{P}$ regeneration, particularly in comparison to carbon, continues to be debated (e.g.,

114 Anderson et al., 2001). Other studies suggest that under reducing conditions, microbial activity

115 is instrumental in controlling $\mathrm{P}$ biogeochemistry by either preferentially releasing $\mathrm{P}$ storage

116 compounds (e.g., polyphosphate), or by converting soluble $\mathrm{P}$ into insoluble apatite forms 
117 (Sannigrahi and Ingall 2005, Goldhammer et al., 2010). Again, the magnitude of this release may

118 vary given the rapid transformation of polyphosphate into apatite, e.g., sink switching (Diaz et

119 al., 2008; Goldhammer et al., 2010). Observations of enhanced P remobilization across

120 oxic/anoxic boundaries in both lacustrine and marine environments imply that over geologic

121 timescales, P remobilization has contributed to redox stabilization of the atmosphere and oceans

122 (Van Cappellen and Ingall 1994). On shorter timescales, enhanced P regeneration in oxygen

123 deficient zones perturbs ecosystems via increasing eutrophication, or by changing relative

124 nutrient availability (Diaz and Rosenberg 2008). Despite increasing evidence that $\mathrm{P}$

125 biogeochemistry is significantly influenced by changing oxygen conditions, mechanisms of these

126 processes and their participants remain poorly understood (Diaz et al., 2008).

127 Continental shelves may only occupy a small area of the oceans, but they are responsible

128 for $15-30 \%$ of global marine production and more than $40 \%$ of seabed carbon sequestration;

129 hence, climate-induced changes in these marginal seas are likely to be more readily apparent

130 than in their more open ocean counterparts (Yool and Fashman 2001, Muller-Karger et al., 2005,

131 Taylor et al., 2012). The Cariaco Basin, located on the northern continental margin of Venezuela,

132 is a euxinic basin having remained anoxic below 250 - $350 \mathrm{~m}$ over the past millennia (Black et

133 al., 2004; Muller-Karger et al., 2010; Scranton et al., 2014). Cariaco Basin surface waters also

134 experience wind-induced seasonal upwelling, a characteristic similar to that of many OMZs

135 (Helly and Levin 2004, Karstensen et al., 2008). Within the Cariaco Basin, water density is

136 relatively homogenous below $200 \mathrm{~m}$ and thus has little influence on structuring the geochemical

137 and biological properties or vertical particle transport through the redoxcline and below (Taylor

138 et al., 2001). Rather, distributions of elemental species and transitions between particulate and

139 dissolved phases within the redoxcline result from an array of reactions catalyzed by a diverse 
140 community of heterotrophic and chemoautotrophic microorganisms (Taylor et al., 2001; 2006,

141 Edgcomb et al., 2011). Previous research has shown that a chemoautotrophic community

142 residing within the Cariaco redoxcline assimilates dissolved inorganic carbon on the same order

143 of magnitude as surface photoautotrophic production (Taylor et al., 2001, Wakeham et al., 2012).

144 Similar to the observed expansion of OMZs in marine systems associated with rising

145 global temperatures (Oschlies et al., 2008, Stramma et al., 2010), a number of changes have been

146 observed in the Cariaco Basin over the past two decades. Intrusions of dense, deep water from

147 the Caribbean Sea have declined, causing a decrease in density and a reduction in the width of

148 the suboxic zone (Scranton et al., 2014). At the same time, as the density in the Cariaco Basin is

149 strongly controlled by temperature, continued increases in surface temperature (Astor et al. 2013)

150 have the potential to enhance stratification and decrease exchange between surface and deep

151 waters. This is further exacerbated by declining surface wind strength caused by climatic shifts

152 in the Intertropical Convergence Zone (ITCZ), which has increased water stratification over time

153 (Taylor et al., 2012). As a result, a large scale shift in the biological community structure from

154 larger to smaller taxa, including nitrogen fixing organisms that have moved deeper into the water

155 column, has also occurred in the basin (Taylor et al., 2012, Montes et al., 2013, Pinckney et al., 156 2015).

157 Investigations of $\mathrm{P}$ geochemistry within sinking particles in the Cariaco Basin suggest 158 that preferential remineralization of particulate $\mathrm{P}$ to the dissolved pool alternates between 159 inorganic and organic P phases, depending on oxygen availability (Benitez-Nelson et al., 2007).

160 Furthermore, a large fraction of the sinking particulate $\mathrm{P}$ pool appears to be comprised of 161 phosphonates that are also preferentially remineralized with increasing depth in the water column 162 (Benitez-Nelson et al., 2004). The source of the phosphonates remains ambiguous, but may be 
163 due to the presence of cyanobacteria in Cariaco Basin surface waters, which have recently

164 become more abundant (Dyhrman et al., 2009, Montes et al., 2013, Pinckney et al., 2015).

165 Suspended particulate $\mathrm{P}$ may serve as an important link between sinking particulate $\mathrm{P}$ and

166 dissolved P phases, especially across the redoxcline where an active microbial community has

167 been consistently observed. This study is the first to investigate the composition and

168 transformation of suspended particulate $\mathrm{P}$ across the Cariaco Basin redoxcline. The results

169 suggest that suspended particulate $\mathrm{P}$ composition is also significantly influenced by oxygen

170 availability and is likely controlled by both abiotic and biotic processes.

171

172 Methodology

173 Sample Site and Collection

174 The Cariaco Basin is the largest, truly marine, semi-permanent anoxic basin in the world

175 (Scranton et al., 2001). Located off the north coast of Venezuela, it is surrounded by a relatively 176 undeveloped coastline that includes several major rivers: the Unari, Tuy, and Neveri. Water 177 exchange with the Caribbean Sea is restricted to the upper $90-140 \mathrm{~m}$ by a sill and is focused 178 through the Tortuga and Centinela channels (Percy et al., 2008, Lorenzoni et al., 2009). The 179 eastern Cariaco Basin is the site of the joint Venezuela - United States CARIACO Ocean Time 180 Series Program, which has collected monthly data on hydrography, primary production, nutrient 181 and carbonate chemistry, sinking flux of particulate matter and many other biogeochemical 182 variables since November 1995 (Thunell et al., 2007, Muller-Karger et al., 2010, Taylor et al., 183 2012). Enhanced seasonal primary production over the Cariaco Basin is driven by wind-induced 184 coastal upwelling. From December to May, the annual southern migration of the ITCZ causes 185 Trade Winds in the southeastern Caribbean to intensify (Benitez-Nelson et al., 2007, Muller- 
186 Karger et al., 2010, Taylor et al., 2012). During this period of coastal upwelling, surface

187 productivity averages $\sim 1.7 \mathrm{~g} \mathrm{C} \mathrm{m}^{-2} \mathrm{~d}^{-1}$ in contrast to less than $\sim 0.99 \mathrm{~g} \mathrm{C} \mathrm{m}^{-2} \mathrm{~d}^{-1}$ during non-

188 upwelling months (Muller-Karger et al., 2001). High surface productivity combined with

189 restricted water exchange results in anoxic waters below $\sim 250 \mathrm{~m}$. The oxic/anoxic interface

190 fluctuates between 250 and $320 \mathrm{~m}$ of depth due to both lateral intrusions of oxygenated waters

191 from the Caribbean Sea and variations in upwelling intensity (Astor et al., 2003, Li et al., 2012,

192 Astor et al., 2013, Scranton et al., 2014). Recent data suggest that the depth of the oxic/anoxic

193 interface has shoaled over the 19 years of the CARIACO Ocean Time Series (Scranton et al.,

194 2014). In this study we define the redoxcline to be the depth range starting from where oxygen

195 begins to exponentially decline to where oxygen concentrations fall below detection.

196 As part of the CARIACO Ocean Time Series Program, microbial abundance and 197 suspended particulate matter samples were collected monthly from April 2008 to April 2012 at

19819 different depths from $1-1310$ m (Table 1). Heterotrophic bacterial net production and dark

199 dissolved inorganic carbon (DIC) assimilation rates were evaluated semi-annually during the 200 same time period and over the same depth range.

Microbial abundance, bacterial net production, dark dissolved inorganic carbon assimilation

203 For microbial abundance, whole-water samples $(200 \mathrm{~mL})$ were preserved with $2 \%$ (final

204 concentration) borate-buffered formaldehyde and stored at $5^{\circ} \mathrm{C}$. Bacteria were enumerated with

205 epifluorescence microscopy using standard acridine orange-stained slides prepared on dark 0.2

206 Nuclepore polycarbonate membranes (Taylor et al., 2006).

207 Heterotrophic bacterial net production (BNP) was estimated by ${ }^{3} \mathrm{H}$-leucine incorporation 208 into protein following the methods of Kirchman (1993) and Taylor et al. (2001). Using a gas- 
209 tight syringe, triplicate samples in $40 \mathrm{~mL}$ Pierce septa vials with no headspace were immediately 210 spiked with $50 \mu 1$ of $\mathrm{N}_{2}$-purged ${ }^{3} \mathrm{H}$-leucine [20 nM final concentration; L-(4,5- $\left.{ }^{3} \mathrm{H}[\mathrm{N}]\right)$-leu; $52 \mathrm{Ci}$

$\left.211 \mathrm{mmol}^{-1}\right]$. Samples were incubated in on-deck water baths for 6-8 hours at ambient temperature in 212 darkness. Following incubation, samples were fixed with cold trichloroacetic acid (TCA; 5\%

213 final concentration) and refrigerated until processing immediately after the cruise. Filter blanks

214 from samples fixed with 5\% TCA immediately after ${ }^{3} \mathrm{H}$-leucine addition were used to correct for

$215{ }^{3} \mathrm{H}$-leucine incorporation into protein over time. In the lab, samples were processed according to 216 Kirchman (1993) and ${ }^{3} \mathrm{H}$-protein precipitates were captured on $0.22 \mu \mathrm{m}$ cellulosic filters 217 (Osmonics). Filters were then dissolved in $0.5 \mathrm{ml}$ ethyl acetate, suspended in Hionic-Fluor 218 scintillation cocktail and radioassayed. BNP was calculated using a conversion factor of $3.1 \mathrm{~kg} \mathrm{C}$ 219 mole $^{-1}$ of leucine incorporation (Kirchman 1993).

220 Chemoautotrophic assimilation of dark DIC was measured by ${ }^{14} \mathrm{C}$-bicarbonate 221 incorporation into particles. Triplicate samples were dispensed into $40 \mathrm{~mL}$ ground glass 222 stoppered bottles and injected with $200 \mu \mathrm{l}$ of chilled $\mathrm{N}_{2}$-purged ${ }^{14} \mathrm{C}$-bicarbonate in an alkaline 223 brine ( $\mathrm{pH} 9.5 ; \mathrm{S}=60$ on practical salinity scale) at the bottom before sealing without a headspace 224 (Tuttle and Jannasch 1973). ${ }^{14} \mathrm{C}$-bicarbonate samples were incubated in parallel with BNP 225 samples for 14-20 hours under conditions minimizing potential oxygen contamination and light 226 exposure. After incubation, particles were collected on $0.22 \mu \mathrm{m}$ cellulosic filters (Osmonics) and 227 then rinsed twice with $5 \mathrm{~mL}$ of filtered seawater adjusted to $\mathrm{pH} 3.5$. Unassimilated ${ }^{14} \mathrm{C}$ was 228 further purged from filters in a saturated $\mathrm{HCl}$ atmosphere for $>1$ hour. Filters were then dried and 229 suspended in Hionic-Fluor scintillation cocktail and radioassayed. Non-biological sorption was 230 corrected for by samples processed immediately after introduction of the radiotracer. Rates of 
231 dark dissolved inorganic carbon (DIC) assimilation were normalized to $\mu \mathrm{M} \mathrm{C} \mathrm{d}^{-1}$ with values of 232 total DIC derived from $\mathrm{pH}$, temperature and alkalinity (Taylor et al., 2001).

234 Suspended particulate matter

235 Water samples for suspended particulate matter analysis were collected in $2 \mathrm{~L}$ opaque 236 polyethylene bottles, immediately filtered through acid-cleaned and pre-combusted $\left(450^{\circ} \mathrm{C}\right.$ at 5 237 hours) Whatman glass fiber filters $(0.7 \mu \mathrm{m}$ nominal pore size $)$, and frozen in the dark until 238 analysis. Total suspended particulate P (TSPP) and suspended particulate inorganic P were 239 determined on all samples using a modification of the Aspila phosphomolybdate method (Aspila 240 et al., 1976, Benitez-Nelson et al., 2007). Briefly, samples for suspended particulate inorganic P 241 were extracted using weak hydrochloric acid, while samples for TSPP were combusted at $550^{\circ} \mathrm{C}$ 242 to convert any organic P to inorganic P prior to extraction (Aspila et al., 1976). Suspended

243 particulate organic $\mathrm{P}$ was determined as the difference between TSPP and suspended particulate 244 inorganic P. To monitor run to run variability and validate analytical accuracy, standard 245 reference materials of tomato leaves (NIST\# 1573a) and estuarine sediment (NIST\# 1646a) were 246 analyzed with each run (Benitez-Nelson et al., 2007). During analysis of suspended particulate 247 inorganic $\mathrm{P}$, it is possible for some organic P compounds, e.g., simple sugars, to be hydrolyzed 248 during analysis, thus inflating suspended particulate inorganic P concentration estimates. We 249 have therefore more appropriately termed this pool suspended soluble reactive P (SSRP). It is 250 also possible that suspended particulate organic $\mathrm{P}$ concentrations may contain non-reactive 251 inorganic compounds, such as inorganic polyphosphates, and we have therefore termed this pool 252 as suspended soluble non-reactive P (SSNP) (Benitez-Nelson 2000). Rather than deciphering the 253 difference between inorganic and organic $\mathrm{P}$, these methods separate $\mathrm{P}$ into pools of different 
254 chemical reactivity. The more reactive pool, SSRP, is presumably more widely bioavailable than

255 SSNP (Benitez-Nelson 2000). SSRP and TSPP were measured with 3\% precision and SSNP, 256 with $5 \%$ precision.

257 In all water column profiles, results from the Aspila TSPP measurements show a large 258 peak in suspended particulate $\mathrm{P}$ within the redoxcline, usually located directly below the depth 259 where oxygen began to decrease exponentially. These peaks equaled or surpassed the suspended 260 P concentrations within the upper $100 \mathrm{~m}$. A subset of these samples was selected from within, 261 above and below the redoxcline TSPP peak for additional sequential extraction analyses. "Within 262 the redoxcline" refers to samples collected between the depths of 230 and $300 \mathrm{~m}$, depending on 263 the depth profile of oxygen concentrations measured for a given month. These samples 264 contained the highest TSPP concentrations. "Above redoxcline" and "Below redoxcline" 265 samples ranged between depths of $160-230 \mathrm{~m}$ and $260-350 \mathrm{~m}$, depending on the given 266 month's redoxcline depth range. TSPP concentrations within these zones dropped by $>30 \%$ 267 from the within redoxcline concentrations. Due to limited sample material availability, filters 268 were combined across monthly cruises to ensure adequate material for analysis. "Within 269 redoxcline" samples contained at most two samples from different cruises, whereas "Above 270 redoxcline" and "Below redoxcline" samples could contain up to five samples from different 271 cruises. Samples were combined across similar depths, years and hydrographic conditions (e.g., 272 upwelling versus non-upwelling periods as defined by Astor et al., 2003). Table S1 catalogues 273 the individual filters combined and used for the analyses described below.

274 A sequential extraction method, SEDEX, was performed on these selected sub-samples 275 from April 2009 to June 2011 to quantify five different inorganic forms of P: 1) loosely-bound P, 276 2) oxide-bound $P, 3$ ) authigenic $P$, 4) detrital $P$, and 5) organic $P$ (Ruttenberg 1992). Due to 
277 small sample sizes and high run to run variability, we report the first two steps as a combined 278 fraction, loosely/oxide-bound P. SEDEX TSPP refers to the sum of both inorganic and organic P 279 fractions (Steps $1-5$ ), SEDEX SSRP refers to the sum of inorganic P fractions (Steps $1-4$; 280 loosely/oxide-bound, authigenic and detrital P) and SEDEX SSNP refers to only the organic P 281 fraction (Step 5; organic P). A standard reference material of tomato leaves (NIST\# 1646a) and 282 estuarine sediment (NIST\# 1573a) were analyzed with each run (Benitez-Nelson et al., 2007). 283 The extractions were analyzed for P concentrations using a modification of the ash hydrolysis 284 technique as described earlier (Aspila et al., 1976, Benitez-Nelson et al., 2007).

285 Aspila TSPP and SEDEX TSPP concentrations agreed within $\pm 10 \%$ and there was no 286 significant difference between Aspila and SEDEX measured TSPP concentrations $(\mathrm{p}>0.3)$. 287 Furthermore, a least squares linear regression between the two different analyses had a slope of 2881.02 indicating a $\sim 1: 1$ relationship. Composition of the P pools, however, differed between the 289 extraction methods. SEDEX SSRP was consistently 10\% lower than Aspila SSRP, suggesting 290 either incomplete digestion of the inorganic P by SEDEX or overestimation of SSRP by Aspila 291 due to oxidation of the organic P fraction. SEDEX SSNP and Aspila SSNP were poorly 292 correlated due to relatively low concentrations and likely loss of SSNP components to other 293 SEDEX fractions. On average, run to run variability in SEDEX was less than $10 \%$ based on 294 repeat measurements of NIST standards. Variability between replicate SEDEX P measurements 295 within a single run averaged less than 5\%.

296 Suspended particulate organic carbon (SPOC) and suspended particulate nitrogen (SPN) 297 concentrations were determined on the same filters as the P analyses following the procedures 298 outlined in Froelich (1980). Briefly, approximately $1 / 4$ to $1 / 2$ of the filter was acidified (1 M 
$\mathrm{H}_{3} \mathrm{PO}_{4}$ ) to remove the particulate inorganic carbon (i.e., carbonates) and then combusted at

$3001000^{\circ} \mathrm{C}$ in a Perkin Elmer 2400 elemental analyzer (Thunell et al., 2007).

\section{Results}

303 Bacteria

304 From April 2008 to April 2012, average prokaryoplankton concentrations tended to 305 follow a bimodal pattern with depth across all seasons (described previously by Taylor et al., 306 2006), but were highly variable (Figure 1A, 1B and 1C). The median surface prokaryote peak 307 from $0-100 \mathrm{~m}$ was $1 \mu \mathrm{M} \mathrm{C}\left(25^{\text {th }}\right.$ percentile $=0.7 \mu \mathrm{M} \mathrm{C}$ and $75^{\text {th }}$ percentile $\left.=2 \mu \mathrm{M} \mathrm{C}\right)$ and the 308 median in redoxcline depths $(230-290 \mathrm{~m})$ was $0.7 \mu \mathrm{M} \mathrm{C}\left(25^{\text {th }}\right.$ percentile $=0.6 \mu \mathrm{M} \mathrm{C}$ and $75^{\text {th }}$

309 percentile $=0.9 \mu \mathrm{M} \mathrm{C})($ Figure 1A). Bacterial net production in the surface peaked at $35 \pm 38 \mathrm{~m}$ 310 and dark DIC assimilation rates peaked within the redoxcline at $268 \pm 26 \mathrm{~m}$. The median dark

311 DIC assimilation rate was $0.2 \mu \mathrm{M} \mathrm{C} \cdot \mathrm{day}^{-1}\left(25^{\text {th }}\right.$ percentile $=0.02 \mu \mathrm{M} \mathrm{C} \cdot$ day $^{-1}$ and $75^{\text {th }}$ percentile $312=0.5 \mu \mathrm{M} \mathrm{C} \cdot$ day $^{-1}$ ) within the redoxcline (Figure 1).

313 For the most part, prokaryoplankton depth profiles complement dissolved oxygen and 314 TSPP profiles, similar to those depicted in the example provided from December 2010: as 315 oxygen becomes depleted, TSPP concentrations increase to form a secondary peak, prokaryotic 316 biomass forms one or more slightly shallower peaks (Figure 2A), while peaks in dark DIC 317 assimilation and BNP are nearly coincident with that of TSPP (Figure 2B). Incongruities 318 between peak positions for prokaryoplankton biomass and chemoautotrophic and heterotrophic 319 production (Figures 2A and 2B) are interpreted as evidence for higher mortality rates within the 320 most productive layer. Enhancements in dark DIC assimilation in the upper $\sim 100 \mathrm{~m}$ likely are 321 caused by anaplerotic reactions occurring in the tricarboxylic acid cycle, a pathway present in all 
322 non-fermenting organisms (Taylor et al., 2001). As the euphotic zone contains the greatest

323 biomass, contributions of anaplerotic reactions are expected to dominate dark carbon fixation in

324 this layer. The majority of TSPP peaks $(93 \%, n=44)$ occurred between 240 and $270 \mathrm{~m}$, as did $32570 \%$ of the peaks in prokaryotic biomass $(n=43)$ (Figure $2 \mathrm{~A}$ inset) and $75 \%$ of the peaks in dark 326 DIC assimilation rates $(\mathrm{n}=8)$ (Figure $2 \mathrm{~B}$ inset).

Suspended Particulate P

Suspended P concentrations in the upper $100 \mathrm{~m}(\mathrm{n}=44)$ were highest at $25 \pm 17 \mathrm{~m}$ 330 (average \pm 1 standard deviation) and averaged $84 \pm 77 \mathrm{nM}$ TSPP, $17 \pm 23 \mathrm{nM} \mathrm{SSRP}$ and $68 \pm 57$

331 nM SSNP (Figures 3A and 3B). Below the upper $100 \mathrm{~m}$, concentrations steadily decreased until 332 reaching the redoxcline. Secondary peaks were always observed between 230 and $290 \mathrm{~m}$ (mean 333 depth $=256 \pm 13 \mathrm{~m}$ ) and TSPP, SSRP, and SSNP averaged $88 \pm 60,54 \pm 53$ and $34 \pm 23 \mathrm{nM}$, 334 respectively. Suspended P declined throughout the deeper anoxic waters (> $300 \mathrm{~m})$.

335 The magnitude of the redoxcline $\mathrm{P}$ peaks was not significantly different between 336 upwelling and non-upwelling seasons (Student t-test, $p>0.05$ ). However, the composition of the 337 TSPP maximum in the upper $100 \mathrm{~m}$ and the redoxcline was significantly different (Figure 3A 338 and 3B). Average SSRP peak concentrations in the redoxcline $(54 \pm 53 \mathrm{nM})$ were as much as 5 $339(3 \pm 2)$ times greater than those associated with the peak in surface waters $(17 \pm 23 \mathrm{nM})$ (Student 340 t-test, $\mathrm{p}<0.00006)$. In contrast, upper $100 \mathrm{~m}$ SSNP peak concentrations $(68 \pm 57 \mathrm{nM})$ were as 341 much as $4.5(2 \pm 2.5)$ times greater than in the redoxcline peaks $(34 \pm 23 \mathrm{nM})$ (Student t-test, $\mathrm{p}<$ 342 0.0007). Thus, SSNP dominated in the surface, while SSRP dominated in the redoxcline. 
From April 2008 to June 2011, TSPP concentrations were measured in a subset of

346 samples from above, within and below the redoxcline using SEDEX $(n=24)$. As SEDEX

347 samples were analyzed for a shorter time period, average P concentrations differ from those

348 averaged over the entire dataset. SEDEX TSPP concentrations were significantly higher within

349 the redoxcline $(143 \pm 26 \mathrm{nM})$ than those above and below the redoxcline $(81 \pm 22$ and $71 \pm 57$

$350 \mathrm{nM}$, respectively) (Student t-test, $\mathrm{p}<0.002$ ). Loosely/oxide-bound P dominated SEDEX TSPP

351 pools within the redoxcline, averaging $111 \pm 24 \mathrm{nM}(79 \pm 12 \%$ of SEDEX TSPP) for all

352 observations, and were significantly different from those above and below the redoxcline

353 (Student t-test, $\mathrm{p}<0.002$; Figure 4A and 4B). In contrast, SEDEX TSPP pools above and below

354 the redoxcline were almost equally comprised of loosely/oxide-bound P, $39 \pm 7 \mathrm{nM}(49 \pm 6 \%$ of

355 SEDEX TSPP) above and $43 \pm 39 \mathrm{nM}(52 \pm 23 \%$ of SEDEX TSPP $)$ below, and organic bound P,

$35635 \pm 7 \mathrm{nM}(44 \pm 8 \%$ of SEDEX TSPP $)$ above and $19 \pm 8 \mathrm{nM}(34 \pm 18 \%$ of SEDEX TSPP) below

357 (Figure 4A and 4B). Authigenic P concentrations did not vary significantly with depth, 358 contributing only $13 \pm 14 \mathrm{nM}(9 \pm 10 \%$ of SEDEX TSPP) within the redoxcline, $5 \pm 6 \mathrm{nM}(6 \pm$ $3597 \%$ of SEDEX TSPP $)$ above, and $9 \pm 19 \mathrm{nM}(13 \pm 8 \%$ of SEDEX TSPP) below the redoxcline.

360 Detrital P was almost undetectable, accounting for $0.5 \pm 1.5 \mathrm{nM}(0.3 \pm 1 \%$ of SEDEX TSPP $)$

361 within the redoxcline, $1 \pm 2 \mathrm{nM}(1.5 \pm 2 \%$ of SEDEX TSPP $)$ above, and $0.2 \pm 0.4 \mathrm{nM}(0.3 \pm$ $3620.6 \%$ of SEDEX TSPP) below the redoxcline. Although SEDEX data is limited, depth-dependent 363 trends in P composition were similar during upwelling (December to April) and non-upwelling 364 seasons, with no significant difference in P speciation.

365

366

C:N:P Ratios 
368 carbon (SPOC) and suspended particulate nitrogen (SPN) in the upper $100 \mathrm{~m}(\mathrm{n}=44)$ were

369 highest at $25 \pm 17 \mathrm{~m}$ and averaged $10 \pm 9 \mu \mathrm{M}$ and $1.0 \pm 0.9 \mu \mathrm{M}$, respectively (Table 1). Average 370 concentrations of SPOC and SPN within the redoxcline maximum (256 $\pm 12 \mathrm{~m})$ were $5 \pm 2 \mu \mathrm{M}$

371 and $0.7 \pm 0.3 \mu \mathrm{M}$, respectively. Both SPOC and SPN were significantly lower within the 372 redoxcline compared to the upper $100 \mathrm{~m}$ (Student $\mathrm{t}$-test, $\mathrm{p}<0.002$ and $\mathrm{p}<0.0005$, respectively).

373 With the exception of the upper $100 \mathrm{~m}$ and redoxcline, SPOC:TSPP and SPN:TSPP ratios

374 were much higher than Redfield (106 C: $16 \mathrm{~N}: 1 \mathrm{P}$ ) and increased slowly with depth to $\sim 400 \mathrm{~m}$,

375 consistent with preferential remineralization of P (Figure 5). Within the redoxcline, however, 376 suspended SPOC:TSPP and SPN:TSPP ratios declined sharply, with significantly lower 377 SPOC:TSPP and SPOC:SSNP ratios averaging $52 \pm 50$ and $208 \pm 221$, respectively, before 378 increasing back to near surface values (Student t-test, $\mathrm{P}<0.005$ ). SPOC:SPN ratios were not 379 significantly different within the redoxcline $(7.5 \pm 4)$, as compared to above $(8.3 \pm 4)$ and below 380 (6.3 \pm 4$)$. The dramatic depth-dependent decreases in SPOC:TSPP and SPN:TSPP ratios are 381 mainly due to the abrupt increase in suspended P across the redox boundary.

\section{Discussion}

Large scale variability in dissolved and particulate $\mathrm{P}$ concentrations has been observed in 385 other redoxclines similar to that of the Cariaco Basin (e.g., Black Sea and Baltic Sea) and 386 attributed to: 1) microbial activity, which converts dissolved into particulate $\mathrm{P}$ during biological 387 growth and vice versa during decomposition (Taylor et al., 2001; 2009) and 2) delivery of iron 388 and manganese, whose colloidal and particulate oxides adsorb and co-precipitate $\mathrm{P}$ or remobilize 389 P into the dissolved phase upon oxide reduction (Dellwig et al. 2010, Diaz et al. 2012). Our 
390 results suggest that suspended $\mathrm{P}$ biogeochemistry is significantly influenced by both of these

391 biotic and abiotic processes within the redoxcline of the Cariaco Basin.

393 Biotic transformations of suspended $P$

394 TSPP concentrations within the Cariaco Basin redoxcline on average were similar or

395 slightly greater than those measured in the upper $100 \mathrm{~m}$ (Figure 3A and 3B). For one cruise

396 (December 2008), TSPP was observed to be almost five times higher in the redoxcline than in

397 the upper $100 \mathrm{~m}$. These large scale enrichments in the redoxcline are similar to patterns observed

398 in other systems, e.g., Effingham Inlet (Diaz et al., 2012). Lorenzoni et al. (2013) showed that

399 while DOC concentrations remain relatively constant across the Cariaco Basin redoxcline,

400 dissolved organic P (DOP) concentrations are elevated, exceeding waters immediately above and

401 below the redoxcline by $\sim 20-40 \mathrm{nM}$. In contrast, dissolved inorganic P concentrations, or

402 phosphate, steadily increase below the mixed layer and across the redox transition, with no

403 obvious peak in phosphate concentrations observed at the redoxcline (Scranton et al., 2014).

404 Microbial biosynthesis is likely a major factor in DOP, SSRP, and SSNP enrichment

405 within the redoxcline. Dark DIC assimilation rates within the redoxcline are often of the same

406 order of magnitude as primary production in the euphotic zone (Taylor et al., 2001), suggesting

407 that microbial production in this layer plays a critical role in $\mathrm{P}$ dynamics. While a significant

408 factor of two enrichment is observed in the redoxcline's SSNP pool relative to that measured

409 immediately above and below, the same is not observed for SPOC or SPN, which results in a

410 sharp decline in suspended SPOC:TSPP ratios within the redoxcline (Figure 5A, 5B and 5C).

411 The lack of an observable redoxcline SPOC or SPN peak is at odds with the clear 1-2 $\mu \mathrm{M}$

412 increase in SPOC concentrations observed within the Cariaco Basin redoxcline in November 
4132007 (Wakeham et al., 2012) and other studies reporting enriched SPOC and SPN concentrations

414 across redox boundaries in other euxinic basins and OMZs (e.g., Wishner et al., 1995, Çoban-

415 Y1ldiza et al., 2006; Pitcher et al., 2011, Diaz et al., 2012). Closer examination of individual

416 profiles for SPOC and SPN suggest that redoxcline peaks in SPOC and SPN concentrations do

417 exist in the Cariaco Basin, but are obscured by high cruise to cruise variability in peak magnitude

418 and depth relative to suspended SPOC and SPN concentrations measured immediately above and

419 below. Regardless, the measured increase in SPOC and SPN periodically observed within the

420 redoxcline is much lower than the increase expected using measured SSNP concentrations and

421 calculating SPOC and SPN using the 106C:16N:1P ratio from Redfield et al. (1963). This

422 argues for preferential accumulation of SSNP in the redoxcline (Table 1 and Figure 5).

423 The decoupling of SSNP from SPOC and SPN may be due to the presence of inorganic

424 polyphosphate. Inorganic polyphosphate is formed during microbial growth within both P-rich

425 and poor environments primarily as intracellular $\mathrm{P}$ storage, but it also has been shown to be

426 involved in gene regulation and can serve as ballast material in Trichodesmium (Romans et al.,

427 1994, Brown et al., 2004, Orchard et al., 2010). Only recently has polyphosphate been

428 emphasized as a critical player in the marine P cycle (Diaz et al., 2008, Bjorkman 2014, Martin

429 et al., 2014). Genes encoding for enzymes critical for polyphosphate metabolism (ppk1, ppk2,

430 and ppkx) commonly occur in the Global Ocean Sampling (GOS) metagenomic database,

431 suggesting broad geographic distribution of polyphosphate utilization (Temperton et al., 2011).

432 Furthermore, prevalence of ppk1 and ppkx genes in the GOS database appear to be inversely

433 proportional to phosphate $\left(\mathrm{P}_{\mathrm{i}}\right)$ concentrations in surrounding waters, suggesting that microbial

434 communities subjected to low or intermittent $\mathrm{P}_{\mathrm{i}}$ supply are more reliant on polyphosphate

435 sequestration strategies than communities in $\mathrm{P}_{\mathrm{i}}$-replete environments (Temperton et al,. 2011). 
437 remobilization of inorganic polyphosphate. In anoxic sediments, however, intracellular 438 polyphosphate has been shown to be hydrolyzed and released back into the dissolved phase 439 (Gächter and Meyer 1993, Sannigrahi and Ingall 2005, Schulz and Schulz 2005, Hupfer et al., 440 2007), although some sulfide-oxidizing bacteria have been shown to convert this released 441 phosphate into apatite (Goldhammer et al., 2010). In Effingham Inlet, concentrations of total 442 particulate phosphorus per bacterial cell increased up to five fold in the redoxcline and 443 polyphosphate was shown to compose a substantial amount of this pool despite high phosphate 444 concentrations (Diaz et al., 2012).

445 We do not have direct evidence of polyphosphate in our samples. Polyphosphate is 446 normally described as a part of the operationally defined organic P fraction in Aspila SSNP and 447 in the SEDEX analysis (Diaz et al., 2012). However, based on the chemical structure and 448 reactivity of polyphosphate, we argue that some of the shorter chain polyphosphate compounds 449 are likely to be observed in the loosely/oxide-bound P fractions as well, given their reaction with 450 citrate bicarbonate solution. Thus, the observed increase in the loosely/oxide-bound $\mathrm{P}$ and 451 within the SSNP pool in the redoxcline is consistent with the presence of a polyphosphate pool 452 (Figures 3 and 4).

453 Furthermore, if we assume an average cellular $\mathrm{C}: \mathrm{P}$ atomic ratio of $41 \pm 16$ for 454 prokaryotes not producing polyphosphate (Vrede et al., 2002), then prokaryotic P-biomass 455 (nucleic acids, phospholipids, etc.) accounts for $77 \% \pm 44,136 \% \pm 135,54 \% \pm 42$, and $102 \% \pm$ 456107 of TSPP in the euphotic, disphotic, redoxcline and euxinic layers, respectively. Prokaryotic 457 P-biomass accounts for a significantly smaller proportion of the TSPP inventory $(\mathrm{p}<0.001$, 458 ANOVA, $n=47$ ) in the redoxcline than in other layers. In the disphotic and euxinic layers, 
459 prokaryotic P-biomass essentially accounts for all TSPP, while phytoplankton in the euphotic

460 layer easily account for the residual $23 \%$ of the TSPP inventory not attributable to prokaryotes.

461 Thiotrophic chemoautotrophic $\varepsilon$-proteobacteria dominate in the Cariaco Basin redoxcline and are

462 known from the GOS database to carry polyphosphate metabolizing genes (Lin et al., 2006,

463 2008, Temperton et al., 2011). These results are supported further by a recent study of intact

464 polar lipids (IPLs) within the Cariaco Basin, which found that phospholipids, although less than

$4651 \mathrm{nM}$ of the TSPP pool, accounted for up to $90 \%$ of IPLs measured within the redoxcline, and

466 are typically associated with a suite of organisms capable of polyphosphate synthesis and

467 remineralization (Wakeham et al., 2012). These facts, coupled with the $46 \%$ shortfall between

468 P-biomass and TSPP inventories in the Cariaco Basin redoxcline, are suggestive of a 469 chemoautotrophic community residing in this layer that likely relies, at least in part, on 470 polyphosphate. It is unclear why else polyphosphate would reside in the redoxcline despite high

471 concentrations of phosphate and DOP (Lorenzoni et al., 2013), but it may be associated with

472 "luxury" uptake and storage (Diaz et al., 2008, Crocetti et al., 2000, Orchard et al., 2010,

473 Goldhammer et al., 2010, Diaz et al., 2012).

474

Abiotic transformation of $P$

476 Trace metal redox reactions are also likely to play an important role in the enrichment of 477 TSPP through the redoxcline of the Cariaco Basin, particularly with regards to the SSRP pool 478 (Dellwig et al., 2010, Li et al., 2012). The "redox shuttle" refers to the formation of P-associated 479 colloids and particulates when reduced metals, particularly manganese and iron, diffuse upward 480 through the redoxcline and rapidly oxidize and scavenge both phosphate and organic $\mathrm{P}$ 481 compounds (Dellwig et al., 2010, Ruttenberg and Sulak 2011). As these oxidized particles sink 
482 back through the redoxcline, they are reduced abiotically thereby releasing the associated $\mathrm{P}$ 483 (Dellwig et al., 2010). Recent evidence suggests that microbial activity may also enhance these 484 oxidation/reduction reactions (Cosmidis et al., 2014). Closer examination of the TSPP pool 485 reveals that a switch occurs from SSNP dominated waters $(81 \%)$ at the surface to SSRP 486 dominated waters $(61 \%)$ within the redoxcline (Figure 3A). The majority of the SSRP 487 enrichment is attributable to loosely/oxide-bound $\mathrm{P}$, which comprises $\sim 80 \%$ of the SSRP pool in 488 the redoxcline compared to $\leq 50 \%$ above and below (Figure 4B). Comparing average 489 concentrations of loosely/oxide-bound $\mathrm{P}$ above and below the redoxcline $(39 \pm 7 \mathrm{nM}$ and $43 \pm 39$ $490 \mathrm{nM}$, respectively) with the much higher average concentrations of loosely/oxide-bound $\mathrm{P}$ within 491 the redoxcline of $111 \pm 24 \mathrm{nM}$, indicates potential in situ production and subsequent loss of $\sim 70$ $492 \mathrm{nM}$ of this highly labile redoxcline P pool (Figure 4A). Such contrasts in P speciation and large 493 enrichments in loosely/oxide-bound $\mathrm{P}$, suggest that redox reactions play a significant role in 494 inorganic $\mathrm{P}$ accumulation in the redoxcline.

495 It is possible that some of the measured increase in redoxcline TSPP pools is due to 496 remineralization of sinking particles and lateral transport from the nearshore rather than due to in 497 situ formation. However, we argue that this is unlikely. For example, Lorenzoni et al. (2009) 498 measured the composition of several intermediate and bottom nepheloid layers derived from the 499 near shore across the continental shelf of the Cariaco Basin. They found a significant enrichment 500 in SSRP with SSNP concentrations similar to that measured in the overlying water column. At 501 the same time, however, SPOC concentrations were also higher, resulting in elevated $502 \mathrm{SPOC} / \mathrm{SSNP}$ ratios within the nepheloid plumes. This is the opposite of that observed within the 503 redoxcline in our study (Figure 5). 
505 also play a role in the observed increase in TSPP concentrations within the redoxcline. Indeed,

506 attenuated particulate P fluxes within the Cariaco Basin below the redoxcline have been

507 described previously for sinking particles (Benitez-Nelson et al., 2004; 2007). However,

508 disaggregation processes would also significantly increase redoxcline SPOC and SPN pools as

509 well, and this is not observed in our dataset. Furthermore, surface suspended P concentrations in

510 the Cariaco Basin have been shown to vary considerably through time, with higher surface water

511 concentrations occurring during upwelling versus non-upwelling periods coincident with higher

512 rates of primary production (Benitez-Nelson et al., 2015). Within the redoxcline, however,

513 suspended P did not significantly vary with time, confirming a decoupling of the surface and

514 redoxcline particles.

\section{The fate of suspended $P$}

517 While much of the TSPP formed within the redoxcline is likely recycled there, it is quite 518 possible that at least a fraction of the redoxcline TSPP escapes to deeper depths. Taylor et al.

519 (2001) found that the flux of sinking particulate organic carbon captured in sediment traps below 520 the redoxcline frequently exceeded that measured in waters from above and argued that mid521 water chemoautotrophic production was an important secondary source of sinking organic

522 carbon in the water column. Other research using a variety of biomarkers suggests that sinking 523 particles and sediments commonly contain organic matter derived from mid-water

524 chemoautotrophic processes in OMZs and euxinic basins, such as the Arabian and Black Seas 525 and the Peru upwelling zone (Wakeham et al., 2007, Saenz et al., 2011). 
While absolute fluxes of sinking inorganic and organic P decline with increasing depth in

527 the water column in the Cariaco Basin (Benitez-Nelson et al., 2007), there are a number of

528 instances when sediment trap P fluxes below the redoxcline $(\sim 400 \mathrm{~m})$ also exceed those

529 measured directly above $(\sim 225 \mathrm{~m})$ during our study period ( $\sim 40 \%$ of samples, data not shown).

530 While these differences in sediment trap fluxes could be due to hydrodynamic issues associated

531 with sediment trap collections (e.g., Buesseler et al., 2007), the enclosed nature of the Cariaco

532 Basin produces a relatively quiescent setting that minimizes those effects. Therefore, it is quite

533 possible that biologically mediated coagulation of suspended particles within the redoxcline

534 enhances the observed "excess" sinking particulate P fluxes measured at depth. Diverse protist

535 communities, now recognized to play major roles in particle coagulation (Sherr and Sherr 1987,

536 Richardson and Jackson 2007), are known to exist within the redoxcline of the Cariaco Basin

537 (Edgcomb et al., 2011) and zooplankton migration and repackaging of material has been

538 observed within the redoxcline of other OMZs (Wishner et al., 2008).

539 Further evidence for an additional redoxcline source of sinking particulate $\mathrm{P}$ at depth is

540 derived from comparison of nutrient ratios. Scranton et al. (2014) noted a dichotomy between

541 the dissolved inorganic N:P ratios measured in Cariaco Basin deep waters (approximately 16:1)

542 relative to the rate of nutrient accumulation $(11: 1)$ and the overall ratio of total $\mathrm{N}: \mathrm{P}$ in the sinking

543 particulate flux (approximately 5:1 to 12.5:1). These authors hypothesized that the ratio

544 difference was due to changes in the relative proportions of sinking particulate source material

545 enriched in $\mathrm{P}$ relative to $\mathrm{C}$ and $\mathrm{N}$ and argued that both terrestrial and redoxcline sources were the

546 likely culprits. Our relatively low $\mathrm{C} / \mathrm{P}$ ratios within the redoxcline suspended pool support the

547 potential for a redoxcline P source to depth. 
While there are a number of studies that have focused on the role of anoxia on the sinking

551 particulate and sedimentary $\mathrm{P}$ pools, few have focused on $\mathrm{P}$ biogeochemistry within water 552 column redoxclines (Ingall et al., 1993, Benitez-Nelson et al., 2007, Jilbert et al., 2013). In this

553 study, suspended particulate $\mathrm{P}$ and its composition within the redoxcline of the Cariaco Basin

554 was examined for the first time. A lack of seasonal variation in redoxcline TSPP dynamics

555 indicates a decoupling from surface processes and in situ production. The significant switch from

556 biologically less available (SSNP) to more labile P forms (SSRP) within the redoxcline suggests

557 suspended $\mathrm{P}$ cycling in the Cariaco Basin is redox sensitive and is cycled through a combination

558 of both a trace metal redox shuttle and polyphosphate accumulation/remobilization.

559 Furthermore, combined with sediment trap data above and below the redoxcline, our results

560 indicate a mid-water redoxcline source of particulate P (Scranton et al., 2014).

561 The Cariaco Basin has undergone a number of physical and biogeochemical changes over

562 the past two decades that have been assessed through the Cariaco Time-Series (Scranton et al.,

563 2014, Astor et al., 2013, Taylor et al., 2012). It is unclear whether the changes in surface

564 processes (e.g., plankton community structure) influence suspended P cycling within the

565 redoxcline (Scranton et al., 2014). However, the processes of suspended P transformation

566 presented here suggest independent in situ production of suspended $\mathrm{P}$ and contribution by

567 coagulation of suspended $\mathrm{P}$ to sinking $\mathrm{P}$ particles. The reduction in oxygen intrusions and size of

568 the redox zone within the Cariaco Basin, however, may influence the magnitude of suspended P

569 cycling within the redoxcline by changing the bacterial community structure and lowering the

570 concentrations of trace elements available for redox scavenging. As such, mid-water cycling of

571 suspended $\mathrm{P}$ and contributions to the sinking particle phase may be reduced, removing an 
572 important sink of $\mathrm{P}$ within the system. This would create a positive feedback to eutrophication

573 via the diffusion of $\mathrm{P}$ enriched waters back to the surface and contribute to the expansion of 574 OMZs in the future.

575 Acknowledgements: We thank Eric Tappa for all $\mathrm{C}$ and $\mathrm{N}$ analyses and Wendy 576 Plessinger for assistance in all $\mathrm{P}$ analyses. We also thank two anonymous reviewers for their 577 thorough reviews that greatly improved the resulting publication. We are indebted to the 578 personnel of the Fundación La Salle de Ciencias Naturales, Estación de Investigaciones Marinas, 579 Isla Margarita (FLASA/EDIMAR), who were responsible for the collection of samples and 580 analyses of some of the data presented here. In particular, we'd like to thank Yrene Astor, Jesus 581 Narvaez, Glenda Arias, Aitzol Arrellano, Javier Campano, Jesus Escalona, Gustavo Fuentes, 582 Laurencia Guzman, Luis Medina, and Jaimie Rojas, who provided invaluable field and 583 laboratory support. We also thank the crew of the R/V Hermano Ginés for their able support at 584 sea. This work was supported by the National Science Foundation, Ocean Sciences Division, 585 Chemical Oceanography Program (NSF, Grants OCE-0752139, OCE-0752014, OCE-1259110, 586 OCE-9216626, OCE-9729284, OCE-9401537, OCE-9729697, OCE-9415790, OCE-9711318, 587 OCE-0963028 and OCE- 0326268), the Consejo Nacional de Investigaciones Cientificas y 588 Tecnológicas (CONICIT, Venezuela, Grant 96280221) and the Fondo Nacional de Ciencia y 589 Tecnología (FONACIT, Venezuela, Grant 2000001702 and 2011000353). 


\section{References}

Anderson, L., Delaney, M. 2001. Carbon to phosphorus ratios in sediments: Implications for nutrient cycling. Global Biogeochemical Cycles. 15: 65-79.

Aspila, K., Agemian, H., Chau, A. 1976. A semi-automated method for the determination of inorganic, organic and total phosphate in sediments. The Analyst. 101: 187-197.

Astor, Y., Muller-Karger, F., Scranton, M. 2003. Seasonal and interannual variation in the hydrography of the Cariaco Basin, Venezuela: implications for basin ventilation. Continental Shelf Research. 23: 125-144.

Astor, Y., Lorenzoni, L., Thunell, R., Varela., R., Muller-Karger, F., Troccoli, L., Taylor, G., Scranton, M., Tappa, E., Rueda, D. 2013. Interannual variability in sea surface temperature and $\mathrm{fCO}_{2}$ changes in the Cariaco Basin. Deep Sea Research Part II: 93: 3343.

Astor, Y., Lorenzoni, L., Scranton, M. Eds. 2014. Handbook of methods for the analysis of oceanographic parameters at the CARIACO Time-series station. Eds. Cuadernos FLASA, Serie Ciencia y Tecnología N 12. Fundación La Salle de Ciencias Naturales, Caracas, Venezuela.

Black, D., Thunnell, R., Kaplan, A., Peterson, L., Tappa, E. 2004. A 2000-year record of Caribbean and tropical North Atlantic hydrographic variability. Paleooceanography. 19: $1-11$.

Benitez-Nelson, C. 2000. The biogeochemical cycling of phosphorus in marine systems. Earth Science Reviews. 51: 109-135.

Benitez-Nelson, C.R., O’Neill Madden, L., Kolowith, L., Pellechia, P., Thunnell, R. 2004. Phosphonates and particulate organic phosphorus cycyling in an anoxic marine basin. Limnology and Oceanography. 49: 1593-1604.

Benitez-Nelson, C., O’Neill Madden, L., Styles, R., Thunnell, R., Astor, Y. 2007. Inorganic and organic sinking particulate phosphorus fluxes across the oxic/anoxic water column of Cariaco Basin, Venezuela. Marine Chemistry 105:90-100.

Benitez-Nelson, C.R., Thunell, R., Pinckney, J., Lorenzoni, L., Montes, E., Muller-Karger, F. Scranton, M., Taylor, G., Varela, R., Astor, Y. 2015. Elemental Composition (C, N and P) of Sinking and Suspended Particulate Matter in the Cariaco Basin, Venezuela. February 2015 ASLO Winter Meeting Granada, Spain

Bennett, E., Carpenter, S., Caraco, N. 2001. Human impact on erodible phosphorus and eutrophication: A global perspective. BioScience. 51: 227-234.

Bjorkman, K. 2014. Polyphosphate goes from pedestrian to prominent in the marine P-cycle. Proceedings of the National Academy of Sciences. 111: 7890-7891.

Brown M., Kornberg A. 2004. Inorganic polyphosphate in the origin and survival of species. Proceedings of the National Academy of Sciences. 101: 16085-16087.

Buesseler, K., Antia, A., Chen, M., Fowler, S., Gardner, W., Gustafsson, Ö., Harada, K., Michaels, A., Rutgers v. d. Loeff, M., Sarin, M., Steinberg, D., Trull, T. 2007. An assessment of the use of sediment traps for estimating upper ocean particle fluxes. Journal of Marine Research. 65: 345-416.

Çoban-Yıldız, Y., Altabet, M., Yilmaz, A., Tuğrul, S. 2006. Carbon and nitrogen isotopic ratios of suspended particulate organic matter (SPOM) in the Black Sea water column. Deep Sea Research Part II. 53: 1875-1892.

Codispoti, L., Flagg, C., Kelly, V., Swift, J. 2005. Hydrographic conditions during the 2002 
SBI process experiments. Deep Sea Research II. 52: 3199-3126.

Correll, D. 1998. The role of phosphorus in the eutrophication of receiving waters: a review. Journal of environmental quality. 27: 261-266.

Cosmidis, J., Benzerara, K., Morin, G., Busigny, V., Lebeau, O., Jézéquel, D., Noëla, V., Dublet, G., Othmane, G. 2014. Biomineralization of iron-phosphates in the water column of Lake Pavin (Massif Central, France). Geochimica et Cosmochimica Acta. 126: 78-96.

Crocetti, G., Hugenholtz, P., Bond, A., Schuler, J., Keller, D., Jenkins, Blackall, L. 2000. Identification of polyphosphate-accumulating organisms and design of $16 \mathrm{~S}$ rRNAdirected probes for their detection and quantification. Applied Environmental Microbiology. 66: 1175-1182

Dellwig, O., Leipe, T., März, C., Glockzin, M., Pollehne, F., Schnetger, B., Yakushev, E., Böttcher, M., Brumsack, H. 2010. A new particulate Mn-Fe-P shuttle at the redoxcline of anoxic basins. Geochimica et Cosmochimica Acta. 74: 7100-7115.

Deutsch, C., Brix, H., Ito, T., Frenzel, H., Thompson, L. 2011. Climate forced variability of ocean hypoxia. Science. 333: 336-339.

Deutsch, C., Berelson, W., Thunell, R., Weber, T., Tems, C., McManus, J., Crusius, J., Ito, T., Baumgartner, T., Ferreira, V., Mey, J., van Geen, A. 2014. Centennial changes in North Pacific anoxia linked to tropical trade winds. Science. 345: 665-668.

Diaz, R., Rosenberg, R. 2008. Spreading dead zones and consequences for marine ecosystems. Science. 321: 926-929.

Diaz, J., Ingall, E., Benitez-Nelson, C., Paterson, D., de Jonge, M., McNulty, I., Brandes, J. 2008. Marine polyphosphate: A key player in geologic phosphorus sequestration. Science. 320: 652-655.

Diaz, J., Ingall, E., Snow, S., Benitez-Nelson, C., Taillefert, M., Brandes, J. 2012. Potential role of inorganic polyphosphate in the cycling of phosphorus within the hypoxic water column of Effingham Inlet, British Columbia. Global Biogeochemical Cycles. 26: 1-13.

Dyhrman, S., Benitez-Nelson, C., Orchard, E., Haley, S., Pellechia, P. 2009. A microbial source of phosphonates in oligotrophic marine systems. Nature Geoscience. 2: 696-699.

Doney, S. 2010. The growing human footprint on coastal and open ocean biogeochemistry. Science. 328: 1512-1516.

Edgcomb, V., Orsi, W., Taylor G., Vdacny, P., Taylor, C., Suarez, P., Epstein, S. 2011. Accessing marine protists from the anoxic Cariaco Basin. ISME J. 5: 1237-1241.

Emerson, S., Jacobs, L., Tebo, T. 1983. The behavior of trace metals in marine anoxic waters: Solubilities at the oxygen-hydrogen sulfide interface. Trace Metals in Sea Water. 9: 579-608.

Fanning, K. 1989. Influence of atmospheric pollution on nutrient limitation in the ocean. Nature 339: 460-463.

Froelich, P. 1980. Analysis of organic carbon in marine sediments. Limnology and Oceanography. 25: 564-572.

Gächter, R., Meyer, J. 1993. The role of microorganisms in mobilization and fixation of phosphorus in sediments. Hydrobiologia. 253: 103-121.

Goldhammer, T., Brüchert, V., Ferdelman, T., Zabel, M. 2010. Microbial sequestration of phosphorus in anoxic upwelling sediments. Nature Geoscience. 3: 557-561.

Helly, J., Levin, L., 2004. Global distribution of naturally occurring marine hypoxia on continental margins. Deep-Sea Research I 51, 1159-1168.

Hupfer, M., Gloess, S., Grossar, H. 2007. Polyphosphate-accumulating microorganisms in 
aquatic sediments. Aquatic microbial ecology: international journal. 47: 299-311.

Ingall, E., Bustin, R., Van Cappellen, P. 1993. Influence of water column anoxia on the burial and preservation of carbon and phosphorus in marine shales. Geochimica et Cosmochimica Acta. 57: 303-316.

Jahnke, R. 1992. The phosphorus cycle. In: Butcher, S., Charlson, R., Orians, G.,Wolfe, G., (Eds). Global Biogeochemical Cycles. New York:Academic Press

Jilbert, T., Slomp, C. 2013. Iron and manganese shuttles control the formation of authigenic phosphorus minerals in the euxinic basins of the Baltic Sea. Geochemica et Cosmochimica Acta. 107: 155-169.

Kalvelage, T., Lavik, G., Lam, P., Contreras, S., Arteaga, L, Loscher, C., Oschlies, A., Paulmier, A., Stramma, L., Kuypers, M. 2013. Nitrogen cycling driven by organic matter export in the South Pacific oxygen minimum zone. Nature Geoscience. 6: 228-234.

Karl D. 1978. Distributions, abundance, and metabolic states of microorganisms in the water column and sediments of the Black Sea. Limnology and Oceanography. 23:936-49.

Karl, D., Dore, J., Fujieki, L., Hebel, D., Houlihan, T., Letelier, R, Tupas, L. 2001. Ecological nitrogen-to-phosphorus stoichiometry at station ALOHA. Deep Sea Research Part II. 48: 1529-1566.

Karl, D. 2014. Microbially mediated transformations of phosphorus in the sea: New views of an old cycle. Annual Review of Marine Science. 6: 279-337.

Karstensen, J. Stramma, L., Visbeck, M. 2008. Oxygen minimum zones in the eastern tropical Atlantic and Pacific oceans. Progress in Oceanography. 77: 331-350.

Kirchman, D. 1993. Leucine incorporation as a measure of biomass roduction by heterotrophic bacteria, p. 509-512. In P.F. Kemp, B.F. Sherr, E. B. Sherr, and J.J. Cole [eds.], Handbook of methods in aquatic microbial ecology. Lewis.

Lam, P., Kuypers, M. 2011. Microbial nitrogen cycling processes in oxygen minimum zones. Annual Reviews of Marine Science. 3: 317-345.

Levin, L. 2003. Oxygen minimum zone benthos: Adaptation and community response to hypoxia. Oceanography and Marine Biology: An Annual Review. 41: 1-45.

Li, X., Cutter, G., Thunell, R., Tappa, E., Gilhooly, W., Lyons, T., Astor, Y., Scranton, M. 2011. Particulate sulfur species in the water column of the Cariaco Basin. Geochimica et Cosmochimica Acta. 75: 148-163.

Li, X., Taylor, G., Astor, Y., Varela, R., Scranton, M. 2012. The conundrum between chemoautotrophic production and reductant and oxidant supply: A case study from the Cariaco Basin. Deep Sea Research I. 61: 1-10.

Lin, X., Wakeham, S., Putnam, I., Astor, Y., Scranton, M., Taylor, G. 2006. Vertical distributions of prokaryotic assemblages in the anoxic Cariaco Basin and Black Sea compared using fluorescent in situ hybridization (FISH). Applied Environmental Microbiology. 72: 2679-2690.

Lin, X., Scranton, M., Chistoserdov, A., Varela, R., Taylor, G. 2008. Spatiotemporal dynamics of bacterial populations in the anoxic Cariaco Basin. Limnology and Oceanography. 53: 37-51.

Lorenzoni, L., Thunell, R., Benitez-Nelson, C., Hollander, D., Martinez, N., Tappa, E., Varela, R., Asor, Y., Muller-Karger, F. 2009. The importance of subsurface nepheloid layes in transport and delivery of sediments to the eastern Cariaco Basin, Venezuela. Deep Sea Research I. 56: 2249-2262.

Lorenzoni, L., Taylor, G., Benitez-Nelson, C., Hansell, D., Montes, E., Masserini, R., 
Fanning,K., Varela, R., Astor, Y., Guzman, L., Muller-Karger, F. 2013. Spatial and seasonal variability of dissolved organic matter in the Cariaco Basin. Journal of Geophysical Research: Biogeosciences. 118: 951-962.

Madrid V., Taylor G., Scranton M., Chistoserdov A. 2001. Phylogenetic diversity of Bacterial and Archaeal communities in the anoxic zone of the Cariaco Basin. Applied Environmental Microbiology. 67:1663-74.

Martin, P., Dyhrman, S., Lomas, M., Poulton, N., Van Mooy, B. 2014. Accumulation and enhanced cycling of polyphosphate by Sargasso Sea plankton in response to low phosphorus. PNAS. 111: 8089-8094.

Matear, R., Hirst, A. 2003. Long term changes in dissolved oxygen concentrations in the ocean caused by protracted global warming. Global Biogeochemical Cycles. 17: 1125.

Montes, E., Thunell, R., Muller-Karger, F., Lorenzoni, L., Tappa, E., Troccoli, L., Astor, Y., Varela, R. 2013. Sources of $\delta 15 \mathrm{~N}$ variability in sinking particulate nitrogen in the Cariaco Basin, Venezuela. Deep Sea Research Part II. 93: 96-107.

Muller-Karger, F., Varela, R., Thunell, R., Scranton, M., Bohrer, R., Taylor, G., Capelo, J., Astor,Y., Tappa, E., Ho, T.Y., Iabichella, M., Walsh, J., Diaz, J. 2000. Sediment record linked to surface processes in the Cariaco Basin. Eos, Transactions, American Geophysical Union. 81(45): 529,534-535.

Muller-Karger F., Varela, R., Thunell, R., Scranton, M., Bohrer, R., Taylor, G., Capelo, J., Astor, Y., Tappa, E., Ho, T., Walsh, J. 2001. Annual cycle of primary production in the Cariaco Basin: Response to upwelling and implications for vertical export. Journal of Geophysical Research. 106: 4527-4542.

Muller-Karger F., Varela, R., Thunell, R., Luerssen, R., Hu, C., Walsh, J. 2005. The importance of continental margins in the global carbon cycle. Geophysical Research Letters. 32: 1-4.

Muller-Karger, F., Varela, E., Thunell, R., Scranton, M., Taylor, G., Astor, Y., Benitez-Nelson, C., Lorenzoni, L., Tappa, E., Goñi, M., Rueda, D., Hu, C. 2010. The CARIACO Oceanographic Time Series. In: Carbon and Nutrient Fluxes in Continental Margins: A Global Synthesis. JGOFS Continental Margins Task Team (CMTT) Editors: K.-K. Liu, L. Atkinson, R. Quinones, L. Talaue-McManus. Springer-Verlag New York. Pp 454-463. Murray, J., Yakushev, E. 2006. The suboxic transition zone in the Black Sea. In: Neretin, L.N. (Ed.) Past and Present Water Column Anoxia, NATO Sci Ser., Springer, Netherlands, p.105-138.

Orchard, E., Benitez-Nelson, C., Pellechia, P., Lomas, M., Dyhrman, S. 2010. Polyphosphate in Trichodesmium from the low phosphorus Sargasso Sea. Limnology and Oceanography. 55: 2161-2169.

Oschlies, A., Schultz, K., Riebesell, U., Schmittner, A. 2008. Simulated 21st century's increase in oceanic suboxia in CO2-enhanced biotic carbon export. Global Biogeochemical Cycles. 22: 1-10.

Paerl, H. 1997. Coastal eutrophication and harmful algal blooms: Importance of atmospheric deposition and groundwater as "new" nitrogen and other nutrient sources. Limnology and Oceanography. 42: 1154-1165.

Paulmier, A., Ruiz-Pino, D. 2009. Oxygen minimum zones in the modern ocean. Progress in Oceanography. 80: 113-128.

Pasek, M.A., Harnmeijer, J., Buick, R., Maheen, G., Atlas, Z. 2013. Evidence for reactive 
reduced phosphorus species in the early Archean ocean. Proceedings of the National Academy of Science USA. 110: 10089-10094.

Pasek, M., Sampson, J., Atlas, Z. 2014. Redox chemistry in the phosphorus biogeochemical cycle. Proceedings of the National Academy of Sciences. 111: 15468-15473.

Paytan, A., McLaughlin, K. 2007. The oceanic phosphorus cycle. Chemical Reviews. 107: 563 576.

Percy, D., Li, X., Taylor, G., Astor, Y., Scranton, M. 2008. Controls on iron, manganese and intermediate oxidation state sulfur compounds in the Cariaco Basin. Marine Chemistry. 111: 47-62.

Pinckney, J., Benitez-Nelson, C., Thunell, R., Muller-Karger, F., Lorenzoni, L., Troccoli, L., Varela, R. 2015. Phytoplankton community structure and depth distribution changes in the Cariaco Basin between 1996 and 2010. Deep Sea Research I. 101: 27-37.

Pitcher, A., Villanueva, L., Hopmans, E., Schouten, S., Reichart, G., Damste, J. 2011. Niche segregation of ammonia-oxidizing archaea and anammox bacteria in the Arabian Sea oxygen minimum zone. The ISME Journal. 5: 1896-1904.

Redfield, A. 1958. The biological control of chemical factors in the environment. American Scientist. 46: 205-222.

Redfield, A., Ketchum, B., Richards, F. 1963. The influence of organisms on the composition of sea-water. In The Sea, vol. 2, edited by M.N. Hill, p 26-77, Interscience, New York.

Richardson, T., .Jackson, G. 2007. Small phytoplankton and carbon export from the surface ocean. Science. 315: 838-840.

Romans, K., Carpenter, E., Bergman, B. 2004. Buoyancy regulation in the colonial diazotrophic cyanobacterium Trichodesmium tenue: Ultrastructure and storage of carbohydrate, polyphosphate and nitrogen. Journal of Phycology. 30: 935-942.

Ruttenberg, K. 1992. Development of a sequential extraction method for different forms of phosphorus in marine sediments. Limnology and Oceanography. 37: 1460-1482.

Ruttenberg, K., Sulak, D. 2011. Sorption and desorption of dissolved organic phosphorus onto iron (oxyhydro)oxides in seawater. Geochemica et Cosmochimica Acta. 75: 40954112.

Saenz, J., Summons, R., Eglinton, T., Wakeham, S., 2011. Distribution of bacteriohopanepolyols in marine anoxic environments: new constraints on the provenance of hopanoids in the marine geologic record. Organic Geochemistry. 42: 1322-1351.

Sannigrahi, P., Ingall, E. 2005. Polyphosphates as a source of enhance P fluxes in marine sediments overlain by anoxic waters: Evidence from 31P NMR. Geochemical Transactions. 6: 52-59.

Scranton, M., Astor, Y., Bohrer, R., Ho, T., Muller-Karger, F. 2001. Controls on temporal variability of the geochemistry of the deep Cariaco Basin. Deep Sea Research I. 48: 1605-1625.

Scranton, M., Taylor, G., Thunell, R., Benitez-Nelson, C., Muller-Karger, F., Fanning, K., Lorenzoni, L., Montes, E., Varela, R., Astor, Y. 2014. Interannual and decadal variability in the nutrient geochemistry of the Cariaco Basin. Oceanography. 27: 148-159.

Schulz, H., Schulz, H. 2005. Large sulfur bacteria and the formation of phosphorite. Science. 307: 416-418.

Sherr, E., Sherr, B. 1987. High rates of consumption of bacteria by pelagic ciliates. Nature. 325 : 710-711. 
Silkin, V., Pautova, L., Pakhomova, S., Lifanchuk, A., Yakushev, E., Chasovnikov, V. 2014. Environmental control on phytoplankton community structure in the NE Black Sea. Journal of Experimental Marine Biology and Ecology. 461:267-274.

Spencer, D., Brewer, P. 1971. Vertical advection diffusion and redox potentials as controls on the distribution of manganese and other trace metals dissolved in waters of the Black Sea. Journal of Geophysical Research. 76: 5877-5892.

Stramma, L., Johnson, G., Sprintall, J., Mohrholz, V. 2008. Expanding oxygen minimum zones in the Tropical Oceans. Science. 320: 655.

Stramma, L., Schmidtko, S., Levin, L., Johnson, G. 2010. Ocean oxygen minima expansions and their biological impacts. Deep Sea Research Part I: Oceanographic Research Papers. 57: 587-595.

Taylor, G., Iabichella, M., Ho, T., Scranton, M., Thunell, R., Muller-Karger, F., Varela, R. 2001. Chemoautotrophy in the redox transition zone of the Cariaco Basin: A significant midwater source of organic carbon production. Limnology and Oceanography. 46: 148163.

Taylor, G., Iabichella-Armas, M., Varela, R., Muller-Karger, F., Lin, X., Scranton, M. 2006. Microbial ecology of the Cariaco Basin's redoxcline: The U.S.-Venezuela CARIACO Time Series Program. In Microbial Ecology of the oxic/anoxic interface.

Taylor, G., Thunell, R., Varela, R., Benitez-Nelson, C., Scranton, M. 2009. Hydrolytic ectoenzyme activity associated with suspended and sinking organic particles within the anoxic Cariaco Basin. Deep Sea Research I. 56: 1266-1283.

Taylor, G., Muller-Karger, F., Thunell, R., Scranton, M., Asor, Y., Varela, R., Ghinaglia, L., Lorenzoni, L., Fanning, K., Hameed, S., Doherty, O. 2012. Ecosystem responses in the southern Caribbean Sea to global climate change. PNAS. 109: 19315-19320.

Temperton, B., Gilbert, J. ., Quinn, J., McGrath, J. 2011. Novel analysis of oceanic surface water metagenomes suggests importance of polyphosphate metabolism in oligotrophic environments. PLoS ONE 6(1): e16499. doi:10.1371/journal.pone.0016499

Thunell, R., Benitez-Nelson, C., Varela, R., Astor, Y., Müller-Karger, F. 2007. Particulate organic carbon fluxes along upwelling-dominated continental margins: Rates and mechanisms. Global Biogeochemical Cycles. 21: GB1022, doi:10.1029/2006GB002793.

Tuttle, J., Jannasch, H. 1973. Sulfide and thiosulfate-oxidizing bacteria in anoxic marine basins. Marine Biology. 20: 64-70.

Van Cappellen, P., Ingall, E. 1994. Benthic phosphorus regeneration, net primary production, and oceanic anoxia: A model of the coupled marine biogeochemical cycles of carbon and phosphorus. Paleoceanography. 9: 677-692.

Van Mooy, B.A.S., Krupke, A., Dyhrman, S.T., Fredricks, H.F., Frischkorn, K.R., Ossolinski, J.E.,, Repeta, D.J.,, Rouco, M., Seewald, J.D., Sylva, S.P. 2015. Major role of planktonic phosphate reduction in the marine phosphorus redox cycle. Science, 348: 783-785.

Vrede, K., Heldal, M., Norland, S., Bratbak, G. 2002. Elemental composition (C, N, P) and cell volume of exponentially growing and nutrient-limited bacterioplankton. Applied Environemtal Microbiology. 68: 2965-2971.

Wakeham, S., Amann, R., Freeman, K., Hopmans, E., Jørgensen, B., Putnam, I., Schouten, S., Sinninghe Damste', J., Talbot, H., Woebken, D. 2007. Microbial ecology of the stratified water column of the Black Sea as revealed by a comprehensive biomarker study. Organic Geochemistry. 38: 2070-2097.

Wakeham, S., Turich, C., Schubotz, F., Podlaska, A., Li, X., Varela, R., Astor, Y., Saenz, J., 
Rush, D., Sinninghe Damste, J., Summons, R., Scranton, M., Taylor, G. Hinrichs, K. 2012. Biomarkers, chemistry and microbiology show chemoautotrophy in a multilayer chemocline in the Cariaco Basin. Deep Sea Research I. 63: 133-156.

Wishner, K., Ashjian, C., Gelfman, C., Gowing, M., Kann, L., Levin, L., Mullineaux, L., Saltzman, J. 1995. Pelagic and benthic ecology of the lower interface of the Eastern Tropical Pacific oxygen minimum zone. Deep Sea Research Part I. 42: 93-116.

Wishner, K., Gelfman, C., Gowing, M., Outram, D., Rapien, M., Williams, R., 2008. Vertical zonation and distributions of calanoid copepods through the lower oxycline of the Arabian Sea oxygen minimum zone. Progress in Oceanography. 78: 163-191.

Wright, Kaye. 2013. Proceedings of the Microbial Ecology and Biogeochemistry of Oxygen Deficient Marine Waters Meeting.

Wyrtki, K. 1962. The oxygen minima in relation to ocean circulation. Deep Sea Research. 9: 11-23.

Wu, J. E, Sunda, W., Boyle, E.A., Karl, D. 2000. Phosphate depletion in the western North Atlantic Ocean. Science. 289: 759-762.

Yool A, Fashman, M. 2001. An examination of the 'continental shelf pump' in an open ocean general circulation model. Global Biogeochemical Cycles. 15:831-844.

883

884 
886 Table 1: Average concentrations at each sampling depth of TSPP (nM), SSRP (nM), SSNP (nM), 887 SPOC $(\mu \mathrm{M})$ and SPN $(\mu \mathrm{M})$ for all months between April 2008 to April 2012. Redoxcline depth 888 range $(230-290 \mathrm{~m})$ is highlighted in grey. Sample size for each depth is presented as n.

890 Figure 1: Box and whisker plot of A) prokaryoplankton, B) bacterial net production, and C) dark 891 DIC assimilation rate weighted means binned from 1-100, 101-229, 230-290 and > $300 \mathrm{~m}$.

892 Weighted means were computed from the layer's integral divided by the layer's depth interval (n 893 represents the number of weighted means represented in each box). Boxes, internal lines, error 894 bars and circles represent the 25 th to 75 th ( $=$ interquartile range), medians, $10^{\text {th }}$ to $90^{\text {th }}$, and $5^{\text {th }}$ to $89595^{\text {th }}$ percentiles of all observations, respectively.

897 Figure 2: Prokaryote distributions and production with depth relative to P and DO. A) Example 898 profile from December 2010 showing prokaryoplankton concentration ( $\mu$ M C), TSPP (nM) and 899 DO $(\mu \mathrm{M})$, Inset: Frequency of TSPP maximum peaks (black bars) and prokaryoplankton 900 maximum peaks (grey bars) at each depth within the redoxcline from April 2008 to April 2012, 901 B) Example profile from December 2010 showing heterotrophic bacterial net production, dark 902 DIC assimilation rate, TSPP (nM) and DO (uM). Inset: Frequency of TSPP maximum peaks 903 (black bars) and dark DIC assimilation rate maximum peaks (grey bars) at each depth within the 904 redoxcline from April 2008 to April 2012.

905

906 Figure 3: Suspended particulate P concentrations with depth. A) Depth profile of SSRP (nM). 907 Grey dots represent individual samples measured for SSRP, while black solid line represents 
908 average SSRP. Dashed line represents average TSPP to illustrate contribution of SSRP to TSPP

909 B) Depth profile of SSNP (nM). Grey dots represent individual samples measured for SSNP, 910 while black solid line represents average SSNP. Dashed line represents TSPP to illustrate 911 contribution of SSNP to TSPP.

912

913 Figure 4: Phosphorus composition across the redoxcline. A) Average concentrations of loosely/ 914 oxide-bound $\mathrm{P}$, authigenic $\mathrm{P}$, detrital $\mathrm{P}$ and organic $\mathrm{P}(\mathrm{nM})$ within the redoxcline (light grey 915 bars), above the redoxcline (black bars) and below the redoxcline (dark grey bars). Error bars 916 represent the standard deviation, B) Percent average concentrations of loosely/oxide-bound P, 917 authigenic $\mathrm{P}$, detrital $\mathrm{P}$ and organic $\mathrm{P}(\mathrm{nM})$ within the redoxcline (light grey bars), above the 918 redoxcline (black bars) and below the redoxcline (dark grey bars). Error bars represent the 919 standard deviation.

920

921 Figure 5: Elemental ratios of suspended particulate matter with depth. A) SPOC:TSPP (black 922 squares) and SPOC:SSNP (white squares), B) SPN:TSPP (black squares) and SPN:SSNP (white 923 squares), and C) SPOC:SPN (black squares). The redoxcline is denoted by the area between the 924 dashed lines. Standard deviations of each ratio (not shown) are on average $\pm 100 \%$, reflecting 925 the high variability of the system. 
Figure 1
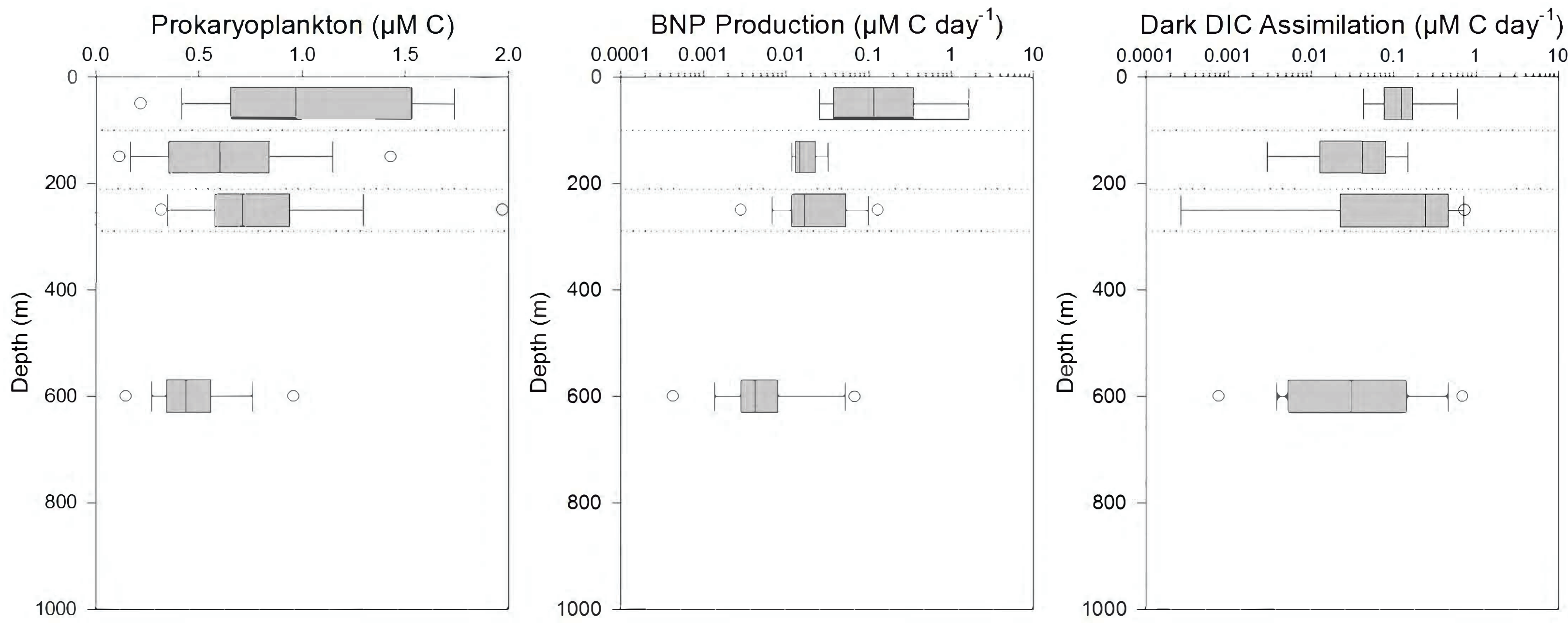


\section{Figure $2 A$}

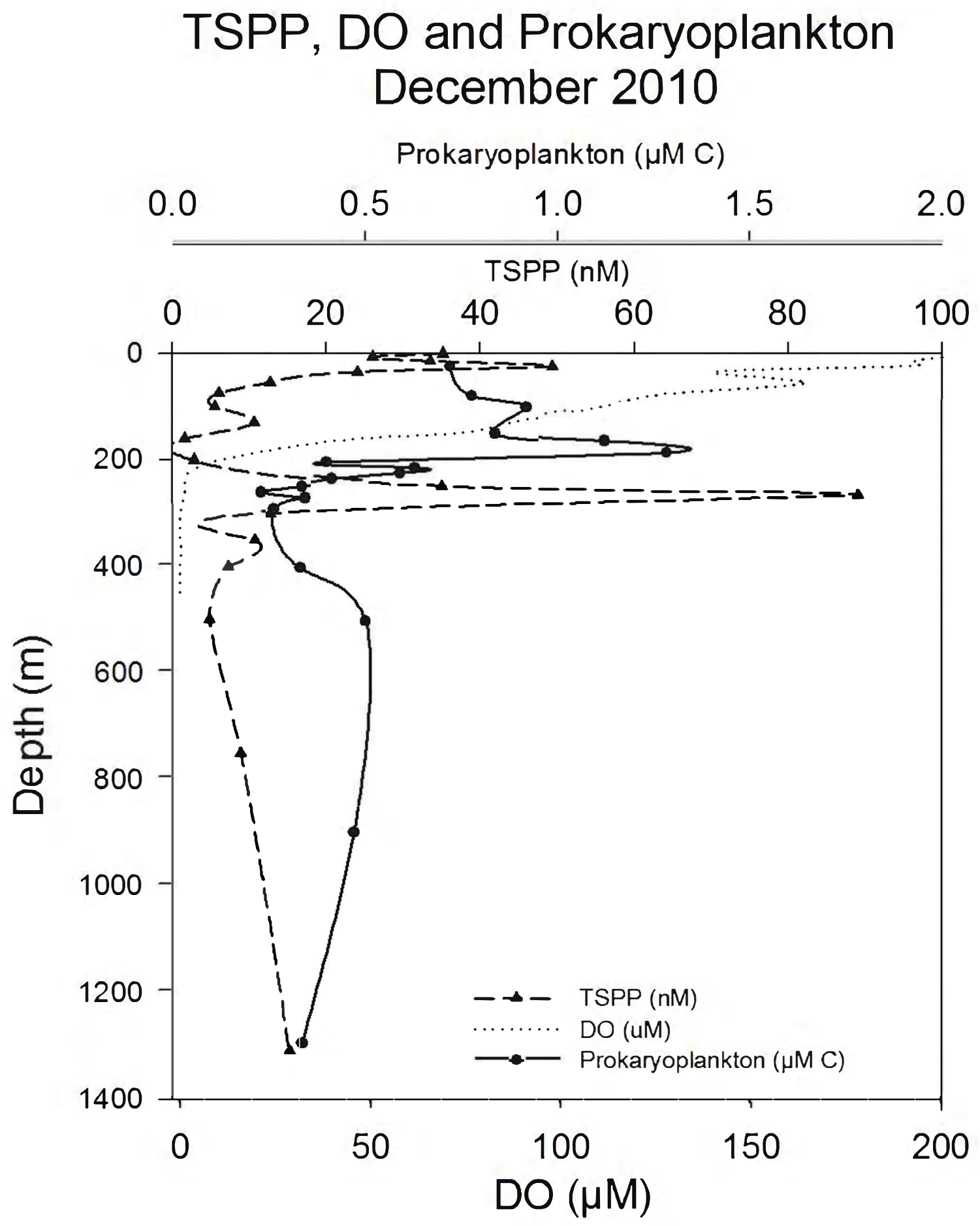


Figure 2Ainsert

Frequen cy of T SPP and Prokaryoplankton Peaks vithin the Redoxdin e

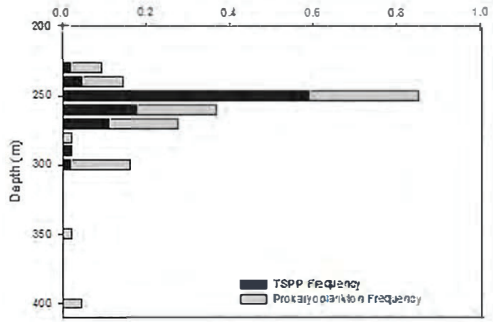




\section{Bacterial Net Production and Dark DIC Assimilation December 2010}

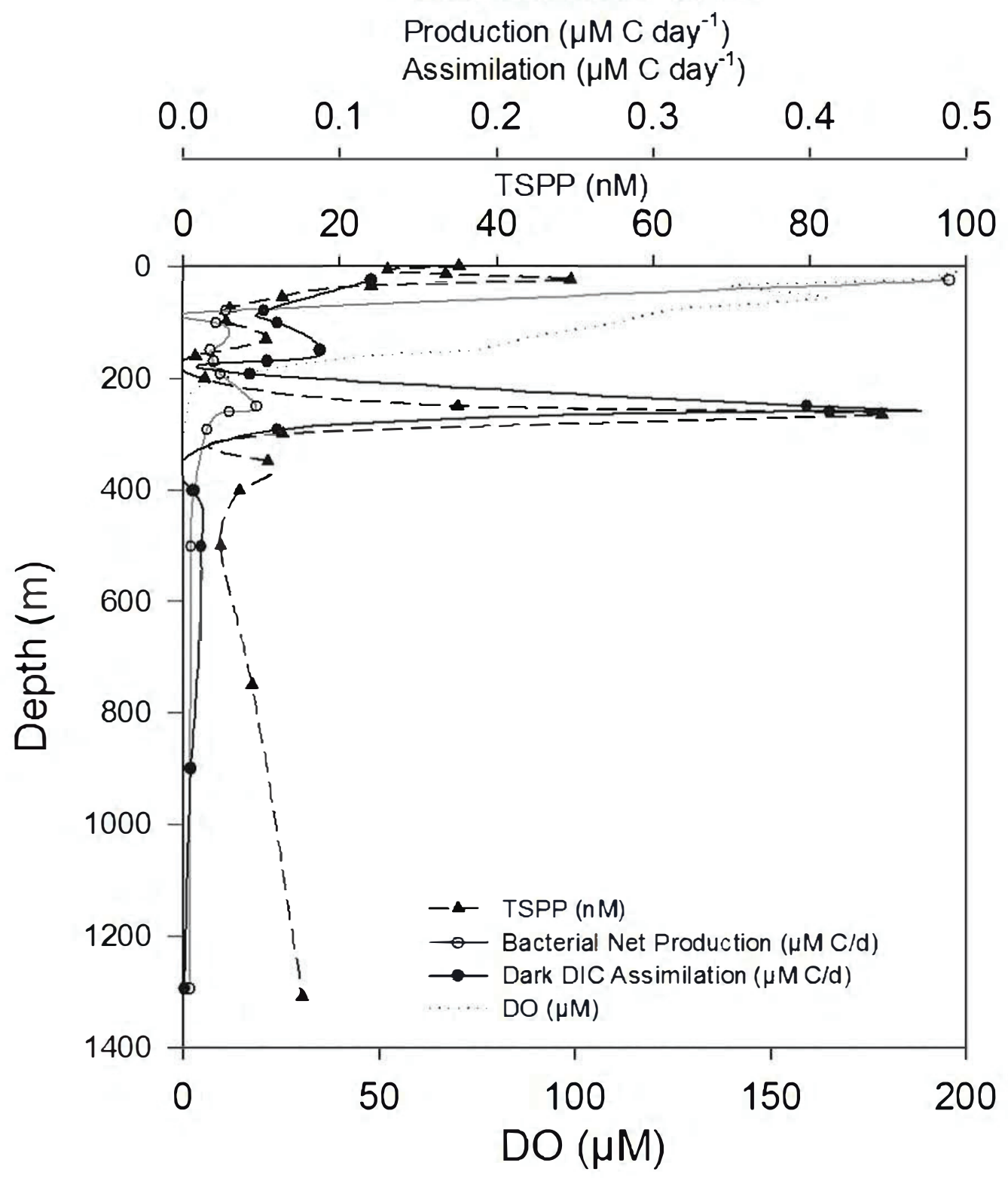


$F$ requency of TSPP and Daik DIC Assimilation P eaks vithin the Redoxdine

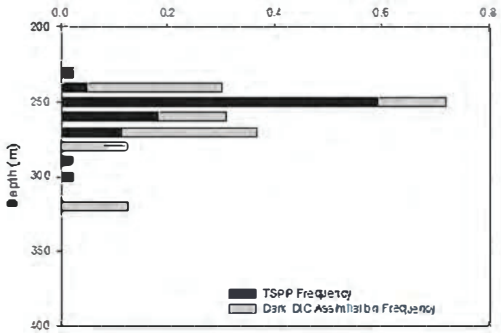




\section{FIG3AB.tiff}
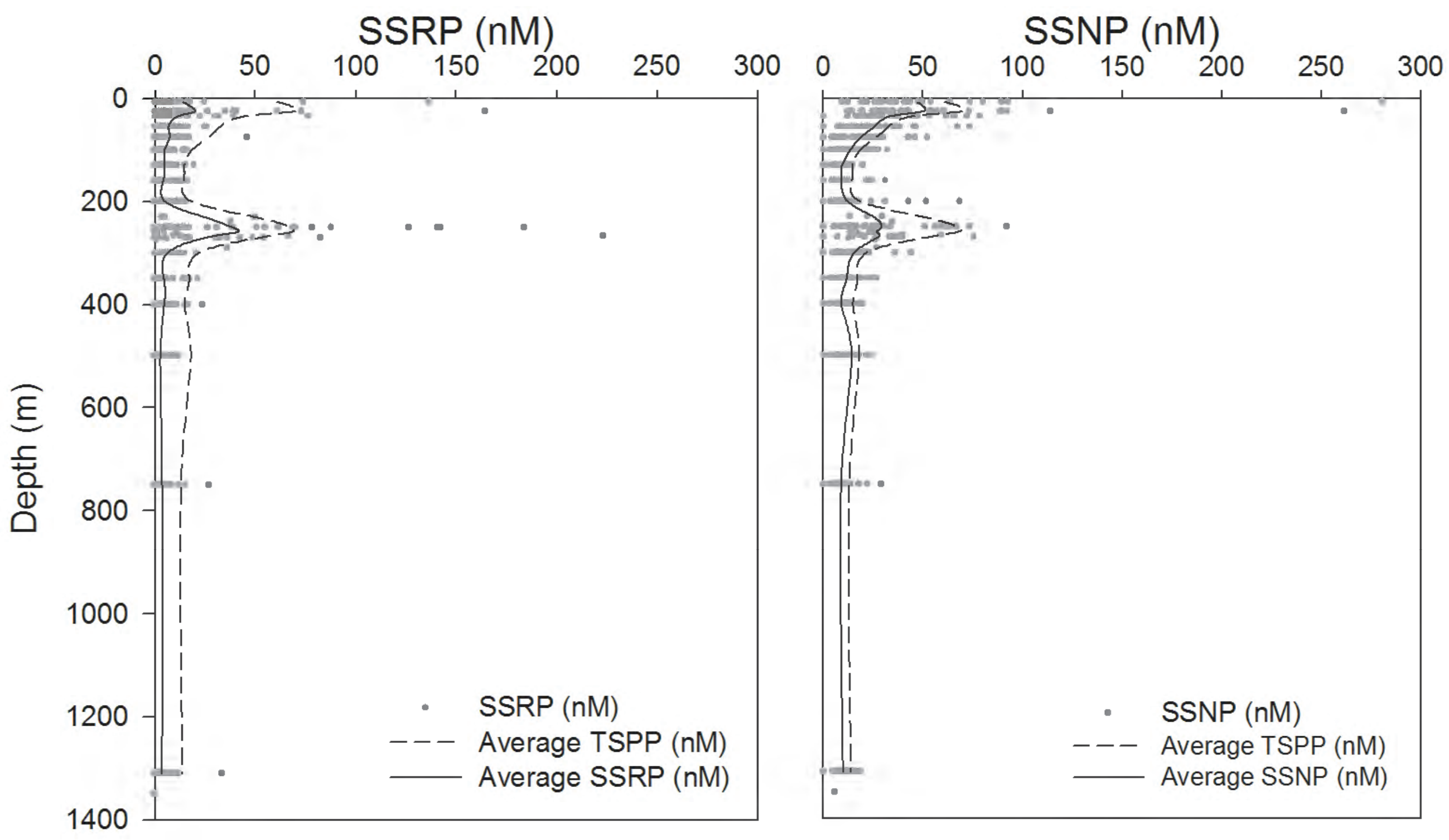


\section{Absolute TSPP Concentrations from SEDEX}

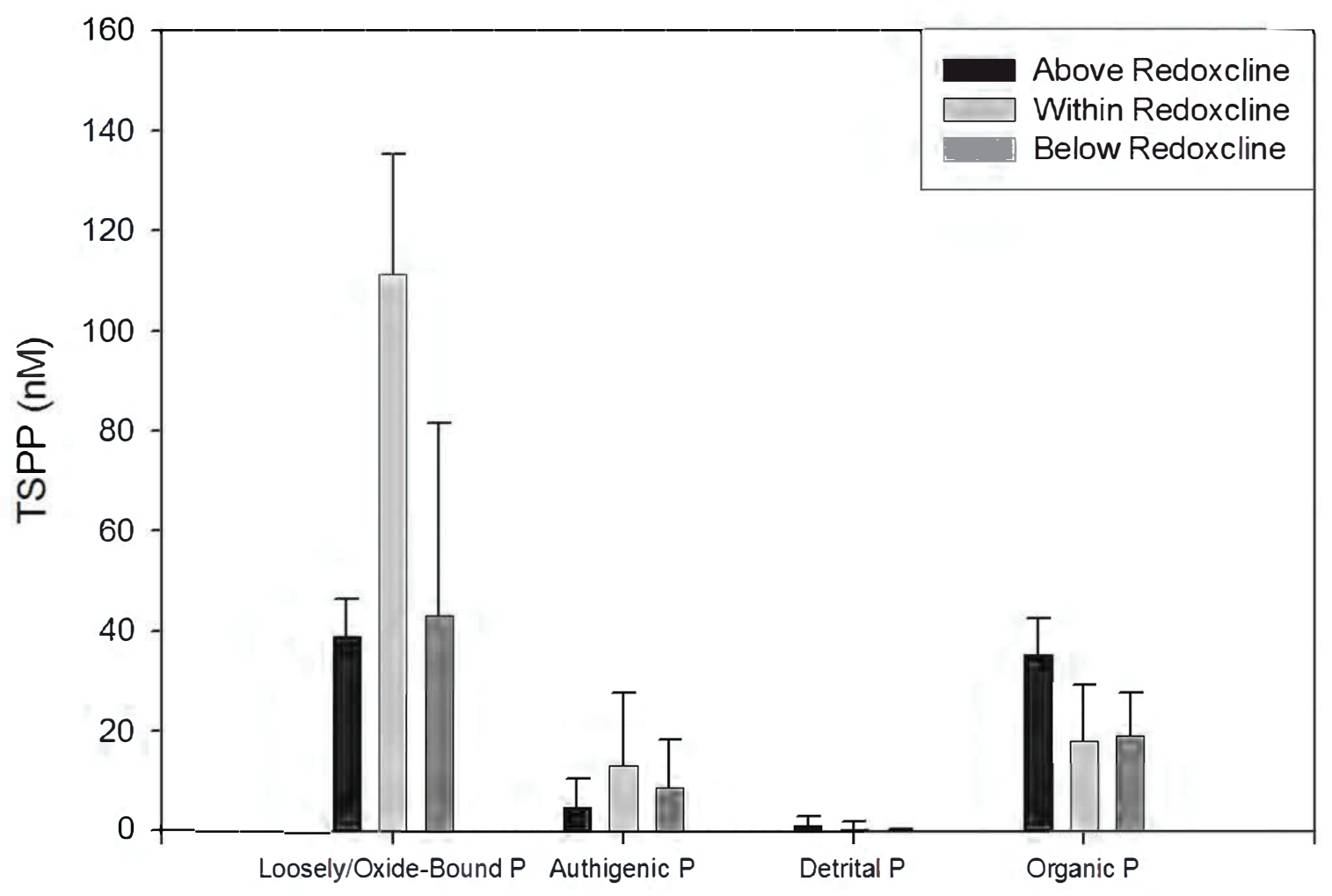




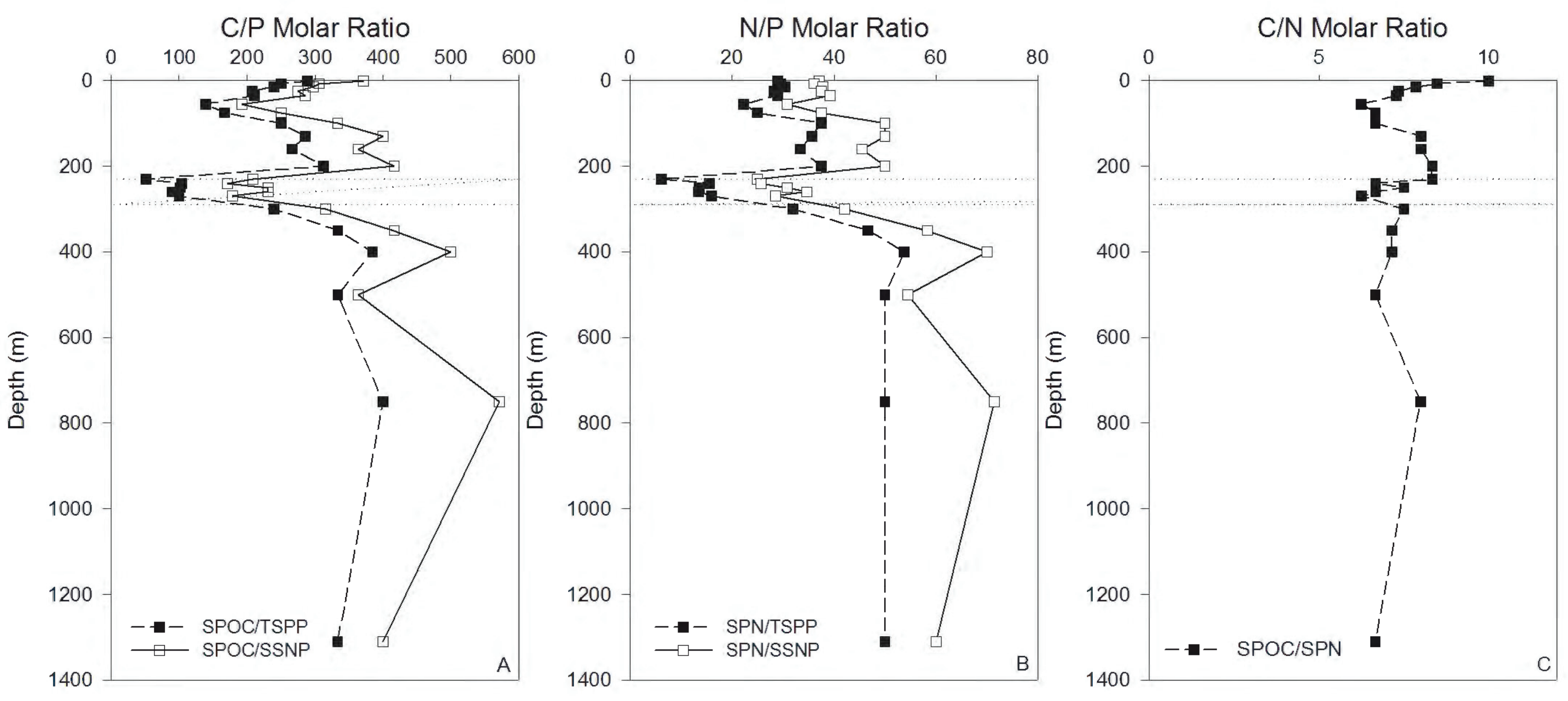


Table 1.pdf

\begin{tabular}{|c|c|c|c|c|c|c|c|c|c|c|c|}
\hline $\mathrm{n}$ & Depth (m) & TSPP (nM) & SD & $\operatorname{SSRP}(n M)$ & SD & $\begin{array}{l}\text { SSNP } \\
\text { (nM) }\end{array}$ & SD & $\begin{array}{l}\text { SPOC } \\
(\mu \mathrm{M})\end{array}$ & SD & SPN $(\mu \mathrm{M})$ & SD \\
\hline 29 & 7 & 60.5 & 74.3 & 13.7 & 26.8 & 46.8 & 49.3 & 8.3 & 8.1 & 1.0 & 0.8 \\
\hline 33 & 25 & 70.2 & 72.2 & 20.0 & 30.5 & 50.2 & 44.7 & 8.7 & 6.0 & 1.2 & 0.9 \\
\hline 34 & 35 & 45.2 & 22.6 & 11.5 & 14.5 & 33.8 & 18.3 & 6.5 & 3.4 & 0.9 & 0.5 \\
\hline 33 & 55 & 32.7 & 18.6 & 7.0 & 6.3 & 25.7 & 16.1 & 6.0 & 1.9 & 0.9 & 0.3 \\
\hline 30 & 75 & 26.9 & 18.8 & 7.5 & 8.8 & 19.0 & 13.2 & 4.7 & 1.6 & 0.7 & 0.3 \\
\hline 37 & 100 & 18.5 & 9.4 & 5.0 & 4.8 & 13.6 & 7.5 & 4.9 & 1.5 & 0.7 & 0.3 \\
\hline 29 & 130 & 14.8 & 7.1 & 4.8 & 5.1 & 9.5 & 5.1 & 4.1 & 1.6 & 0.6 & 0.3 \\
\hline 28 & 160 & 14.5 & 9.4 & 4.3 & 4.6 & 9.3 & 7.6 & 4.0 & 1.8 & 0.6 & 0.3 \\
\hline 37 & 200 & 18.0 & 15.5 & 5.0 & 4.7 & 11.9 & 14.5 & 4.8 & 2.0 & 0.6 & 0.3 \\
\hline 3 & 230 & 48.9 & 31.6 & 24.1 & 23.4 & 24.8 & 9.3 & 5.2 & 1.7 & 0.7 & 0.3 \\
\hline 36 & 250 & 67.5 & 49.8 & 38.2 & 46.2 & 29.4 & 22.2 & 5.5 & 1.4 & 0.7 & 0.2 \\
\hline 7 & 260 & 67.9 & 91.2 & 41.1 & 76.7 & 26.8 & 15.2 & 5.9 & 1.2 & 0.9 & 0.2 \\
\hline 14 & 270 & 53.7 & 30.5 & 26.1 & 23.7 & 27.6 & 18.2 & 5.3 & 1.3 & 0.8 & 0.3 \\
\hline 39 & 300 & 21.7 & 11.3 & 6.1 & 6.7 & 15.3 & 8.2 & 8.1 & 8.8 & 1.1 & 1.3 \\
\hline 35 & 350 & 17.3 & 7.4 & 4.7 & 5.9 & 11.8 & 7.2 & 6.3 & 3.7 & 0.8 & 0.4 \\
\hline 38 & 400 & 14.9 & 6.5 & 4.7 & 5.5 & 9.1 & 5.8 & 8.2 & 7.8 & 1.1 & 1.2 \\
\hline 36 & 500 & 18.1 & 28.9 & 2.8 & 3.7 & 14.3 & 27.6 & 7.3 & 6.3 & 1.1 & 1.0 \\
\hline 34 & 750 & 13.2 & 9.4 & 3.8 & 5.5 & 9.0 & 6.2 & 5.5 & 2.6 & 0.8 & 0.4 \\
\hline 34 & 1310 & 14.0 & 7.6 & 3.7 & 6.3 & 10.0 & 4.3 & 4.9 & 2.3 & 0.7 & 0.3 \\
\hline
\end{tabular}

